\title{
Electrophysiological Characterization of Networks and Single Cells in the Hippocampal Region of a Transgenic Rat Model of Alzheimer's Disease
}

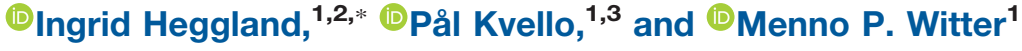

\author{
https://doi.org/10.1523/ENEURO.0448-17.2019
}

\begin{abstract}
${ }^{1}$ Kavli Institute for Systems Neuroscience and Centre for Neural Computation, Egil and Pauline Braathen and Fred Kavli Centre for Cortical Microcircuits, Norwegian University of Science and Technology (NTNU), Trondheim NO7491, Norway, ${ }^{2}$ Liaison Committee between the Central Norway Regional Health Authority (RHA), the Norwegian University of Science and Technology (NTNU), Trondheim NO-7491, Norway, ${ }^{3}$ Department of Teacher Education, Norwegian University of Science and Technology (NTNU), Trondheim NO-7491, Norway
\end{abstract}

\begin{abstract}
The hippocampus and entorhinal cortex (EC) are areas affected early and severely in Alzheimer's disease (AD), and this is associated with deficits in episodic memory. Amyloid- $\beta(A \beta)$, the main protein found in amyloid plaques, can affect neuronal physiology and excitability, and several AD mouse models with memory impairments display aberrant network activity, including hyperexcitability and seizures. In this study, we investigated single cell physiology in EC and network activity in EC and dentate gyrus (DG) in the McGill-R-Thy1-APP transgenic rat model, using whole-cell patch clamp recordings and voltage-sensitive dye imaging (VSDI) in acute slices. In slices from transgenic animals up to 4 months of age, the majority of the principal neurons in Layer II of EC, fan cells and stellate cells, expressed intracellular $\mathrm{A} \beta(\mathrm{iA} \beta)$. Whereas the electrophysiological properties of fan cells were unaltered, stellate cells were more excitable in transgenic than in control rats. Stimulation in the DG resulted in comparable patterns in both groups at three and nine months, but at 12 months, the elicited responses in the transgenic group showed a significant preference for the enclosed blade, without any change in overall excitability. Only transient changes in the local network activity were seen in the medial EC (MEC). Although the observed changes in the McGill rat model are subtle, they are specific, pointing to a differential and selective involvement of specific parts of the hippocampal circuitry in $A \beta$ pathology.
\end{abstract}

Key words: entorhinal cortex; fan cell; intracellular; neuronal excitability; stellate cell; voltage-sensitive dye imaging

\section{Significance Statement}

The hippocampal region, essential for episodic memory, is affected in the early stages of Alzheimer's disease (AD). Here, we use the McGill-R-Thy1-APP transgenic rat model to study the effects of Amyloid- $\beta$ $(A \beta)$ pathology on networks and single cells in the hippocampal region. In young animals, we observed widespread intracellular $\mathrm{A} \beta(\mathrm{i} A \beta)$ accumulation, which later progressed to extracellular plaques. However, the in vitro physiology was largely unaltered, with only changes in single cell excitability of stellate cells in Layer II of MEC and network activation patterns in dentate gyrus (DG). Thus, these two components of the entorhinal-hippocampal network emerge as potentially more vulnerable in the context of $A \beta$ pathology.

Received December 22, 2017; accepted January 21, 2019; First published February 2, 2019.

The authors declare no competing financial interests.
Author contributions: I.H. and M.P.W. designed research; I.H. and P.K. performed research; I.H. analyzed data; I.H., P.K., and M.P.W. wrote the paper. 


\section{Introduction}

Alzheimer's disease (AD), the most common cause of dementia, is a progressive neurodegenerative disorder. The neuropathological hallmarks include extracellular amyloid plaques and intracellular neurofibrillary tangles consisting of hyperphosphorylated tau, as well as cortical atrophy and cell loss. Areas affected by plaques and tangles in early stages of $A D$ include the entorhinal cortex (EC) and the hippocampus (Braak and Braak, 1991; Thal et al., 2002). Neuron loss has been reported in subregions of the hippocampus (West et al., 1994; Simić et al., 1997; Price et al., 2001), and in particular Layer II of EC exhibits a substantial cell loss in patients in the early stages of $A D$ as well as with mild cognitive impairment (Gómez-Isla et al., 1996; Kordower et al., 2001). The two main groups of principal neurons in Layer II, stellate cells in medial EC (MEC) and fan cells in lateral EC (LEC; Canto and Witter, $2012 a, b)$, provide input to the hippocampus via the perforant path (Cappaert et al., 2015). In transgenic mice, it has been shown that both tau and amyloid- $\beta(\mathrm{A} \beta)$ pathology can spread through transsynaptic transmission, starting in EC (Harris et al., 2010; de Calignon et al., 2012), further implicating the entorhinal-hippocampal region in early stages of AD.

The original "amyloid cascade hypothesis" was formulated 25 years ago (Hardy and Higgins, 1992). Although the exact role of $A \beta$ in the initiation and progression of $A D$ is still highly debated, it is clear that $A \beta$ is an important contributor to the pathologic processes (Herrup, 2015; Musiek and Holtzman, 2015). The research focus has shifted to include effects of soluble forms of $A \beta$ (Haass and Selkoe, 2007) and $A \beta$ peptide levels have been shown to have a higher correlation with cognitive decline than amyloid plaque load does (McLean et al., 1999; Näslund et al., 2000). Studies have shown toxic effects of $\mathrm{A} \beta$ oligomers on synaptic function and structure (Selkoe, 2008; Marchetti and Marie, 2011), which could lead to disruption of the normal neuronal function and subse-

This work was supported by the Kavli Foundation, the Helse Midt-Norge Grant 46056620, The Norwegian Research Council (Equipment Grant 181676; Centre of Excellence scheme: Centre for Neural Computation, Grant 223262, and the National Infrastructure scheme: NORBRAIN1, Grant 197467), and the Department of Neuroscience, Faculty of Medicine, Norwegian University of Science and Technology.

*I. Heggland's present address: Section for Collections and Digital Services, NTNU University Library, Norwegian University of Science and Technology (NTNU), Trondheim NO-7491, Norway.

Acknowledgements: We thank Dr. A. Claudio Cuello (McGill University, Montreal, Canada) for providing breeding pairs for our colony of McGill-RThy1-APP transgenic rats. We also thank Hanne T. Soligard for genotyping the rats, and for assistance with histology and immunostaining together with Bruno Monterotti and Stefano Bradamante; Noriko Koganezawa for technical training and advice on the VSDI recordings; Debora Ledergerber for advice and practical help with the electrophysiological recordings; Paulo Girão for assisting with data analysis; Øyvind Salvesen for advice on statistical methods; and Maximiliano Jose Nigro for discussions about this manuscript.

Correspondence should be addressed to Menno P. Witter at menno.witter@ntnu.no.

https://doi.org/10.1523/ENEURO.0448-17.2019

Copyright (C) 2019 Heggland et al.

This is an open-access article distributed under the terms of the Creative Commons Attribution 4.0 International license, which permits unrestricted use, distribution and reproduction in any medium provided that the original work is properly attributed. quent aberrant network activity (Palop and Mucke, 2010a). Recent studies report changes in single neuron excitability in mouse models, including pyramidal cells of CA1 (Brown et al., 2011; Kerrigan et al., 2014), and frontal cortex (Kellner et al., 2014), as well as EC (Marcantoni et al., 2013; Xu et al., 2015) and dentate gyrus (DG; Hazra et al., 2013). Additionally, intracellular delivery of $A \beta$ has been shown to increase neuronal excitability (Scala et al., 2015), and intracellular $A \beta(\mathrm{i} A \beta)$ is found in $E C$ and hippocampus of AD patients (Gouras et al., 2000; D'Andrea et al., 2002). As intracellular accumulation and cognitive deficits have been observed in animal models before formation of plaques (Billings et al., 2005; Leon et al., $2010)$, it is hypothesized that $i A \beta$ may play an important role in neuronal dysfunction in $A D$ (Bayer and Wirths, 2010).

In this study, we use the McGill-R-Thy1-APP transgenic rat model which harbors human $A \beta$ precursor protein $(A \beta P P)$ with the Indiana and Swedish double mutations (Leon et al., 2010), and is one of the few rat models with a progressive plaque pathology. The first plaques appear in the subiculum at nine months of age and then spread to other parts of the hippocampus as well as EC (Heggland et al., 2015). A subtle cell loss $(\sim 20 \%)$ has also been reported in the subiculum at 18 months (Heggland et al., 2015). By one week after birth, iA $\beta$ is observed (Leon et al., 2010), and Layer II of EC is one of the areas with initial high expression (Kobro-Flatmoen et al., 2016). From three months, the rats display cognitive impairments (lulita et al., 2014) and metabolic alterations (Nilsen et al., 2014), and pre-plaque inflammation and changes in longterm potentiation have been described at later ages (Hanzel et al., 2014; Qi et al., 2014). In the present study, we investigated changes in excitability and activity patterns of the networks of the hippocampus and EC in acute slices. We used young pre-plaque animals, when only iA $\beta$ accumulation is present, as well as older animals, when plaques have started to appear. With the use of whole-cell patch clamp recording in acute slices from young animals, we investigated possible changes in the excitability of stellate and fan cells in Layer II of EC. We also assessed whether changes in electrophysiological properties at the network level were related to the developing pathology over time, with the use of voltage-sensitive dye imaging (VSDI).

\section{Materials and Methods}

\section{Animals}

All the experimental procedures were approved by the Local Animal Research Authority and followed the European Convention for the Protection of Vertebrate Animals used for Experimental and Other Scientific Purposes. The animals were kept on a 12/12 h light/dark cycle under standard laboratory conditions $\left(19-22^{\circ} \mathrm{C}, 50-60 \%\right.$ humidity) and had free access to food and water. A colony of transgenic McGill-R-Thy1-APP rats, based on two breeding pairs obtained from McGill University (Leon et al., 2010), was maintained at our university. The McGill-RThy1-APP rats carries the human $A \beta P P_{751}$ including the Swedish double mutation and the Indiana mutation under 
the control of the Thy 1.2 promoter. Quantitative PCR (qPCR) was used to decide the genotype of the transgenic rats (negative, homozygous or hemizygous for the transgene). Genomic DNA was isolated from samples of ear tissue with a High Pure PCR Template Preparation kit (11796828001, Roche Diagnostics). The transgene (human $A \beta P P$ ) and a normalization gene (GAPDH or $\beta$-actin) were detected using $\mathrm{RT}^{2}$ qPCR Primer Assays from QIAGEN (PPH05947A, PPR06557, and PPR06570C) with FastStart Universal SYBR Green Master (04913850001, Roche Diagnostics) on an Applied Biosystems StepOnePlus real-time PCR system (Life Technologies Ltd, Thermo Fisher Scientific). The $\Delta \Delta \mathrm{C}_{\mathrm{T}}$ values were calculated from the GPCR with a known homozygous sample as reference (Livak and Schmittgen, 2001).

\section{Slice preparation}

For the VSDI, homozygous $(+/+)$ transgenic rats and wild-type control animals (wt; WistarHan, Taconic) of both sexes at the ages of three, nine, and 12 months were used. For whole-cell patch clamp recordings, homozygous $(+/+)$ transgenic rats and negative $(-/-)$ littermates of both sexes at the ages of one and three to four months were included. The animals were anesthetized with isoflurane (IsoFlo vet., Abbott Laboratories), decapitated and the brain quickly removed from the skull and placed in ice-cold $\left(0-4^{\circ} \mathrm{C}\right)$, oxygenated $\left(95 \% \mathrm{O}_{2} / 5 \% \mathrm{CO}_{2}\right)$ artificial CSF (ACSF) solution containing: $100 \mathrm{mM} \mathrm{D-mannitol,} 119$ $\mathrm{mM}$ choline chloride, $2.5 \mathrm{mM} \mathrm{KCl}, 7 \mathrm{mM} \mathrm{MgCl}_{2}, 0.5 \mathrm{mM}$ $\mathrm{CaCl}_{2}, 25 \mathrm{mM}$ glucose, $1.25 \mathrm{mM} \mathrm{NaH} \mathrm{PO}_{4}, 25 \mathrm{mM}$ $\mathrm{NaHCO}_{3}, 11.5 \mathrm{mM}$ sodium ascorbate, and $3 \mathrm{mM}$ sodium pyruvate. For rats of three months and older, a transcardial perfusion with ice-cold ACSF was done before decapitation, to remove blood and cool down the brain as quickly as possible.

For VSDI, the brain was cut in $400-\mu$ m-thick horizontal entorhinal-hippocampal slices on a vibratome (Vibratome 300 sectioning system, Vibratome). Slices ranged from approximate interaural levels $2.4-4.68 \mathrm{~mm}$ (Paxinos and Watson, 2007), containing mid to ventral levels of the hippocampus. The slices were placed on a membrane filter (JHWP01300, Omnipore membrane filter, PTFE, Merck Millipore) glued to a thin Plexiglas ring (11-mm inner diameter, 15-mm outer diameter) and held in a oxygenated moist interface chamber at $32^{\circ} \mathrm{C}$ for at least 1 $\mathrm{h}$ before transfer to the recording chamber. For holding and recording, the following ACSF was used: $126 \mathrm{mM}$ $\mathrm{NaCl}, 3 \mathrm{mM} \mathrm{KCl}, 2 \mathrm{mM} \mathrm{MgSO}{ }_{4}, 2 \mathrm{mM} \mathrm{CaCl}, 10 \mathrm{mM}$ glucose, $1.2 \mathrm{mM} \mathrm{NaH}_{2} \mathrm{PO}_{4}$, and $26 \mathrm{mM} \mathrm{NaHCO}_{3}$.

For whole-cell patch clamp recordings, entorhinal slices of $400 \mu \mathrm{m}$ were cut on a vibratome (Leica VT1000S, Leica Biosystems), either in the horizontal or semicoronal plane $\left(20^{\circ}\right.$ angle with the vertical plane). Horizontal slices from middle dorsoventral levels, approximately interaural 2.9-4.4 mm (Paxinos and Watson, 2007), were used for recording MEC II cells, with the majority of the recorded cells found in the center of the mediolateral axis within each slice. Semicoronal slices were used for recording LEC II cells close to the rhinal fissure, at approximate rostrocaudal levels of $4.3-6 \mathrm{~mm}$ posterior to bregma
(Paxinos and Watson, 2007). The slices were held in a submersion chamber with ACSF containing: $126 \mathrm{mM}$ $\mathrm{NaCl}, 3 \mathrm{mM} \mathrm{KCl}, 3 \mathrm{mM} \mathrm{MgCl}, 0.5 \mathrm{mM} \mathrm{CaCl}_{2}, 10 \mathrm{mM}$ glucose, $1.2 \mathrm{mM} \mathrm{NaH}_{2} \mathrm{PO}_{4}$, and $26 \mathrm{mM} \mathrm{NaHCO}_{3}$ at $37^{\circ} \mathrm{C}$ for $1 \mathrm{~h}$, and then at room temperature until recording.

\section{VSDI}

The slice was perfused with oxygenated ACSF at $34^{\circ} \mathrm{C}$ in a recording chamber mounted on a fluorescent microscope (Axio Examiner.D1, Carl Zeiss), and stained with the voltage-sensitive dye $\mathrm{RH} 795(0.5 \mathrm{mg} / \mathrm{ml}$ ACSF; R-649, Invitrogen, Invitrogen, Life Technologies, Thermo Fisher Scientific) for $3 \mathrm{~min}$, and the excess dye was washed out by perfusion of ASCF for 15 min before recording. The slice was illuminated from a halogen lamp $\left(\mathrm{MHAB}_{150} \mathrm{~W}\right.$, Moritex) through a bandpass excitation filter $(535 \pm 25 \mathrm{~nm})$ and a dichroic mirror (half reflectance wavelength of $580 \mathrm{~nm}$ ), and the dye emission was passed through a longpass filter (50\% transmittance at 590$)$ and detected with a CMOS-camera $(100 \times 100$ pixel array; MiCAM Ultima, Brainvision). For the three-month age group, a non-immersion Zeiss Fluar objective was used $(\mathrm{NA}=0.25)$. For the nine- and 12-month groups, a waterimmersion objective from Brainvision $(\mathrm{NA}=0.35)$ was used, as we obtained this after the three-month group was recorded. A shutter (HL-151, Brainvision) controlled by the Brainvision acquisition software built into the light source was opened $500 \mathrm{~ms}$ before the start of the recording to reduce mechanical noise. The images were acquired at $1.0 \mathrm{~ms} /$ frame for 512 frames, and the first 50 frames were used to measure the optical baseline. An extracellular stimulation was applied after $50 \mathrm{~ms}$ with a tungsten bipolar electrode (tip separation of $150 \mu \mathrm{m}$ ) using either a single pulse with an amplitude of 0.2 or 0.6 $\mathrm{mA}$ of 300- $\mu \mathrm{s}$ duration, or four pulses at a frequency of 40 $\mathrm{Hz}$ with an amplitude of $0.2 \mathrm{~mA}$. Eight recordings separated by $3 \mathrm{~s}$ were averaged to reduce noise. The stimulation electrode was placed in different areas of the hippocampal region: the border of the molecular and granule layer of the DG and Layers II/III of entorhinal. In the nine- and 12-month age group, the majority of the slices (38 of 44 slices) were also recorded with the GABA antagonist bicuculline added to the ACSF $(5 \mu \mathrm{m}$; bicuculline methiodide; 14343 , Sigma-Aldrich), to block the inhibition in the slice.

\section{Whole-cell patch clamp}

All single cell recordings were performed at $34^{\circ} \mathrm{C}$ with perfusion of oxygenated ACSF containing: $126 \mathrm{mM} \mathrm{NaCl}$, $3 \mathrm{mM} \mathrm{KCl}, 1.5 \mathrm{mM} \mathrm{MgCl}_{2}, 1.6 \mathrm{mM} \mathrm{CaCl}_{2}, 10 \mathrm{mM}$ glucose, $1.2 \mathrm{mM} \mathrm{NaH}_{2} \mathrm{PO}_{4}$, and $26 \mathrm{mM} \mathrm{NaHCO}_{3}$. Principal cells in Layer II of MEC and LEC were identified using infrared differential interference contrast (IR-DIC) on an Axio Examiner.D1 microscope (Carl Zeiss) with a Zeiss PlanApochromat water dipping objective (20×; NA = 1.0), or an Olympus BX51WI microscope (Olympus) with an Olympus LC Plan FL objective $(40 \times$; NA $=0.8)$. Recording pipettes pulled from standard-walled borosilicate capillaries (3-8 M $\Omega$ pipette resistance; GC120F-10, Harvard Apparatus, Harvard Bioscience) were filled with intracellular solution containing: $120 \mathrm{mM} \mathrm{K}$-gluconate, $10 \mathrm{mM}$ 
$\mathrm{KCl}, 10 \mathrm{mM}$ HEPES, $4 \mathrm{mM} \mathrm{MgATP}, 10 \mathrm{mM} \mathrm{Na} \mathrm{Na}_{2}$ phosphocreatine, and $0.3 \mathrm{mM}$ GTP. Biocytin (3-4\%; B4261, Sigma-Aldrich) was added to the recording solution for later anatomic analysis of cell location and morphology. For a few of the cells ( $n=34$ cells), an Alexa Fluor hydrazide dye (405, 488, 468, or 633; Invitrogen, Invitrogen, Life Technologies, Thermo Fisher Scientific) was added to the intracellular solution instead of biocytin. Whole-cell recordings in current clamp mode were performed on two different setups. Recordings on the first setup was done with MultiClamp 700A and 700B amplifiers (Molecular Devices, Molecular Devices) in bridge mode and digitized with an InstruTECH ITC-1600 A/D interface (HEKA Elektronik) in combination with the acquisition software Chartmaster (HEKA). The second setup was equipped with a Multiclamp 700B amplifier and data were acquired with an InstruTECH ITC-18 board (HEKA) and the acquisition software Patchmaster (HEKA; RRID: SCR_000034). Recordings were made at sampling rates of 10,25 , or $50 \mathrm{kHz}$, depending on the length of the recording. Capacitance compensation was maximal and series resistance was compensated, and the seal resistance was above $1 \mathrm{G} \Omega$. We did not correct for the liquid junction potential, which was calculated to be $15.8 \mathrm{mV}$.

To study general electrophysiological properties and firing frequencies of neurons, voltage responses to a series of 1-s-long current steps of 50 or 30 pA starting from - 300 pA were recorded. A protocol of 10-pA steps starting from $0 \mathrm{pA}$ was used to measure the rheobase. In addition, we injected a sinusoidal current with a linearly increasing frequency (from 0 to $20 \mathrm{~Hz}$ ) with a duration of 15 s, a so-called ZAP-protocol (Erchova et al., 2004), while recording the membrane voltage, and estimated the resonance frequency (frequency with largest amplitude response). In 11 cells, the resonance frequency could not be estimated, due to traces with noise or action potentials (APs).

\section{Histology}

After recordings, the slices were fixed for minimum $24 \mathrm{~h}$ in $4 \%$ freshly depolymerized paraformaldehyde (w/v in $125 \mathrm{mM}$ PB, pH 7.4) and then transferred to $20 \%$ glycerol and $2 \%$ dimethyl sulfoxide (DMSO) in $125 \mathrm{mM} \mathrm{PB.}$

The slices from VSDI were subsequently cut at $50 \mu \mathrm{m}$ on a freezing microtome (Microm HM430, Thermo Fischer Scientific). Half of the sections were mounted directly on Histobond $^{+}$slides and stained with cresyl violet to verify the regions of activity seen with the VSDI. After drying overnight on a heating plate $\left(37^{\circ} \mathrm{C}\right)$ the sections were dehydrated in ethanol, cleared in xylene and rehydrated before staining with cresyl violet $(1 \mathrm{~g} / \mathrm{l})$ for $10-15 \mathrm{~min}$. The sections were then alternately dipped in ethanol-acetic acid (5-ml acetic acid in 1-I 70\% ethanol) and rinsed with cold water until the desired differentiation was obtained, then dehydrated, cleared in xylene and coverslipped with Entellan (Merck KGaA).

The other half of the sections were stained with freefloating immunohistochemistry using the monoclonal antihuman $A \beta$ antibody McSA1 (MM-0015-P; MédiMabs; RRID: $A B$ _1807985), which is specific for human $A \beta$ and stains both plaques and intracellular deposits (Grant et al., 2000; Leon et al., 2010). First, heat-induced epitope retrieval (HIER) was done at $60^{\circ} \mathrm{C}$ for $2 \mathrm{~h}$ in $\mathrm{PB}$. After washing with $\mathrm{PB}(2 \times 10 \mathrm{~min})$ the tissue was permeabilized with $0.5 \%$ Triton $X-100$ in Tris-buffered saline (TBS$\mathrm{TX} ; 50 \mathrm{mM}$ Tris and $150 \mathrm{mM} \mathrm{NaCl}$; pH 8.0) for $10 \mathrm{~min}$ and blocked with $10 \%$ goat serum in TBS-TX for $30 \mathrm{~min}$, before overnight incubation at $4^{\circ} \mathrm{C}$ with the primary antibody, McSA1 (1:4000). The following day, the sections were washed with TBS-TX $(3 \times 10 \mathrm{~min})$ and incubated with a biotinylated goat anti-mouse secondary antibody (1:200, Sigma-Aldrich) for 90 min. After washing (TBS-TX; $3 \times 10 \mathrm{~min})$, incubation in $A B C$ (PK-4000, Vectastain ABC kit, Vector Laboratories) for 90 min, washing with TBS-TX $(3 \times 10 \mathrm{~min})$ and Tris- $\mathrm{HCl}(50 \mathrm{mM}$ Tris adjusted to $\mathrm{pH} 7.6$ with $\mathrm{HCl} ; 2 \times 5 \mathrm{~min}$ ), and the sections were incubated in $0.67 \%$ diaminobenzidine (DAB) with $0.024 \% \mathrm{H}_{2} \mathrm{O}_{2}$ in Tris$\mathrm{HCl}$ for $30 \mathrm{~min}$. After a final wash with Tris- $\mathrm{HCl}(2 \times 5 \mathrm{~min})$, the sections were mounted on Superfrost slides, dried overnight on heating plates, cleared with xylene and coverslipped with Entellan. A Zeiss Axio Imager.M1 microscope (Carl Zeiss) with a CX9000 camera (MBF Bioscience) was used to take brightfield photomicrographs of the sections, which were further processed with Adobe Photoshop CS6 (Adobe Systems; RRID: SCR_014199).

The slices from single-cell recordings were processed to visualize the morphology of the cells and to determine the intracellular expression of $A \beta$. HIER was applied at $60^{\circ} \mathrm{C}$ for $2 \mathrm{~h}$ in $\mathrm{PB}$, and the slices were then washed $2 \times$ 15 min in PB at room temperature followed by $5 \times 15$ min wash in $0.5 \%$ Triton X-100 in TBS-TX and incubation with the primary antibody, McSA1 (1:1000), at $4^{\circ} \mathrm{C}$ for $4 \mathrm{~d}$. After rinsing $5 \times 15$ in TBS-TX, the slices were incubated overnight in room temperature with Alexa Fluor 488 conjugated to streptavidin (1:300; S11223) and a goat antimouse secondary antibody conjugated with Alexa Fluor 546 (1:200; A11003, Invitrogen). A subset of the slices was stained with the opposite combination of fluorophores (Alexa Fluor 546 streptavidin, S11225 and Alexa Fluor 488 goat anti-mouse, A11001). Subsequently, the sections were washed $3 \times 15$ min with TBS-TX, mounted, and coverslipped. The slices were scanned using a laser scanning confocal microscope (LSCM; LSM 510, Carl Zeiss) to determine the cell morphology and intracellular expression of $A \beta$. Alexa Fluor 488 was excited by an Argon/2 laser and the emission was registered through a 505- to 550-bandpass filter, whereas Alexa Fluor 546 was excited by a DPSS 461-10 laser and the emission was bandpass filtered at 575-615.

\section{Analysis of VSDI data}

The Brainvision analysis software (BV_Ana) was used to analyze the optical signals. Changes in membrane potential cause proportional changes in the emission of the voltage sensitive dye (Grinvald et al., 1988), and these were evaluated as fractional changes in the fluorescent signal $(\Delta F / F)$. All the optical signals were processed using spatial and cubic filters in BV_Ana. The first 50 frames were used as the average baseline, and the fractional 
A
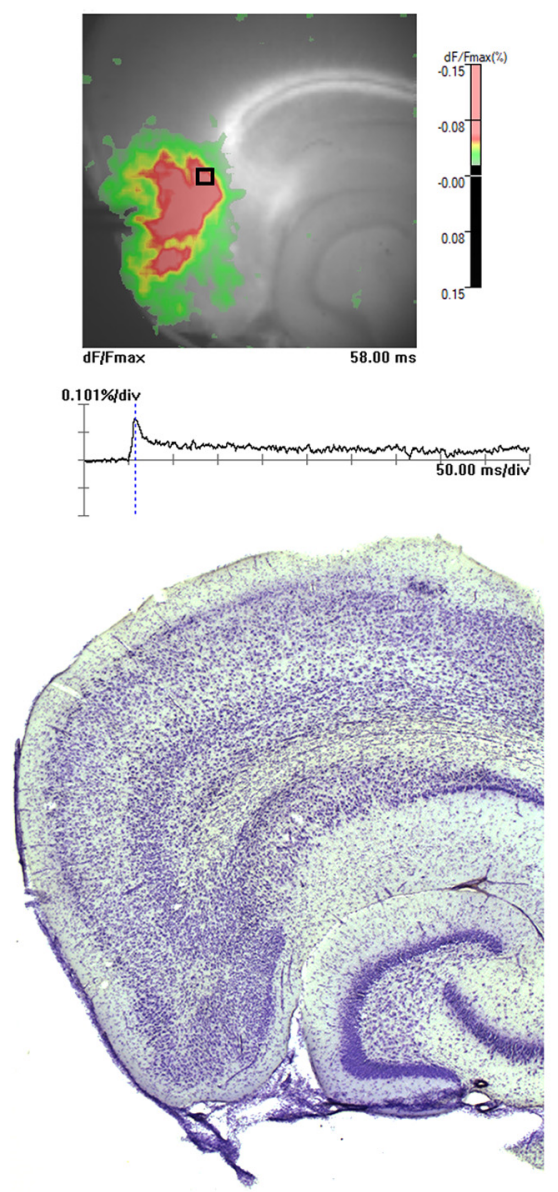

\section{B}
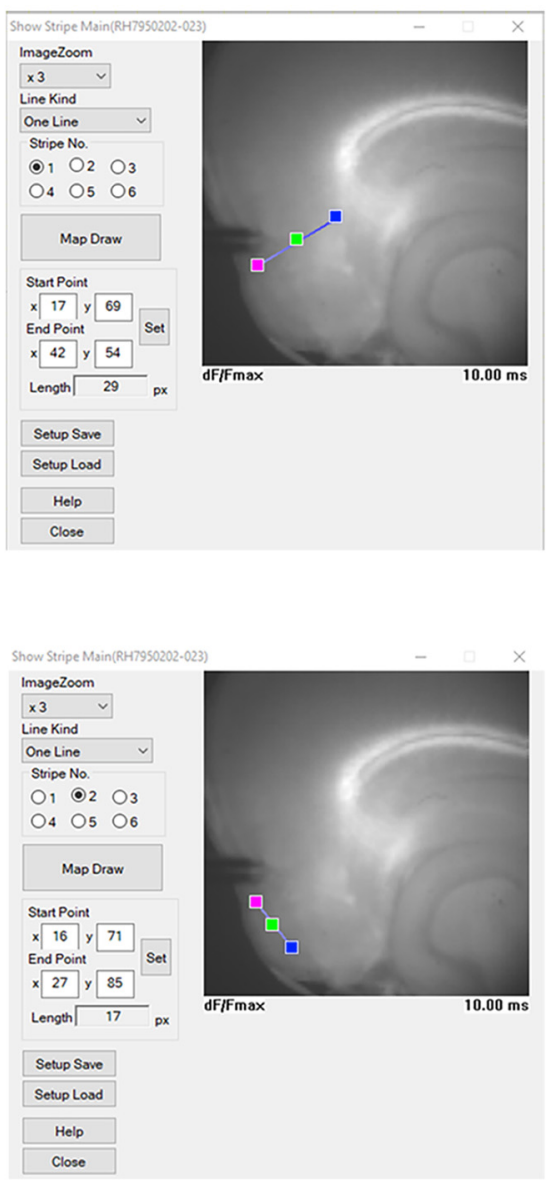
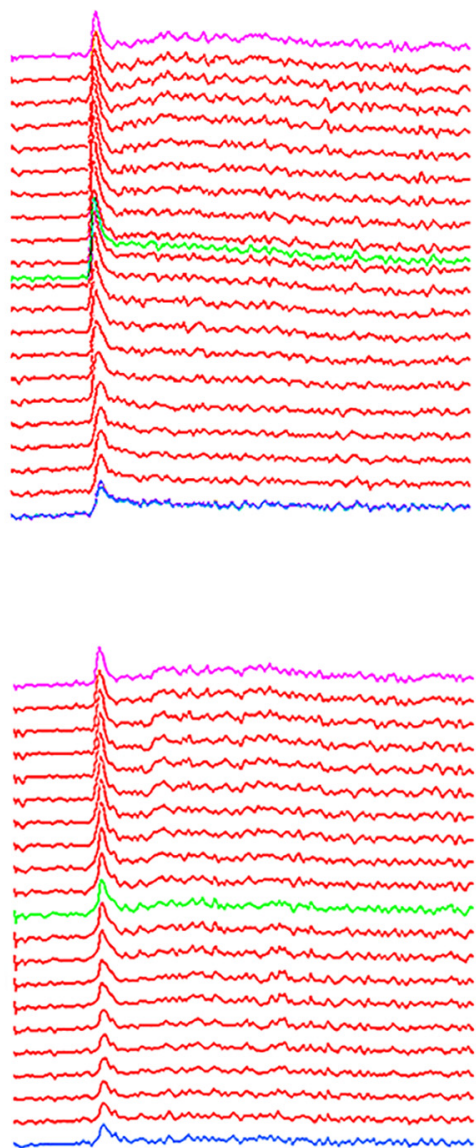

Figure 1. $\boldsymbol{A}$, Example of VSDI imaging with stimulation in MECII in a horizontal slice (top) and the corresponding Nissl stain after histology (bottom). $\boldsymbol{B}$, Illustration of regions of interest (stripes) chosen to analyzed the VSDI signals in MEC, across layer (top left) and within the superficial layers (bottom left). To the right the corresponding traces for the voxels along the stripe is shown with the traces taken from the three color-coded voxels represented with the corresponding color.

optical signals were color-coded and superimposed on a brightfield image to represent the spread of neural activity in the slice (Fig. 1A). In the recordings from DG stimulation, we quantified the neural activation by calculating the integral (area under the curve) from optical traces in voxels in the molecular layer of DG and CA3, as this measure would represent the magnitude of the total membrane potential changes (Koganezawa et al., 2008). In addition, the total activated area in the whole slice after DG stimulation was quantified as the total number of pixels above threshold, with the threshold set to be $0.05 \% \Delta \mathrm{F} / \mathrm{F}$. The paired-pulse ratio (PPR) was calculated by dividing the maximal amplitude of second pulse by the first pulse, with a pulse interval of $25 \mathrm{~ms}$. This was done for the voxels in each of the two blades of DG and an overall average PPR for DG was calculated for each slice. In recordings with stimulation in superficial MEC, stripes of voxels were analyzed. This was done both across layers and within the superficial layers in MEC, to evaluate the spread of the signal in the local network (Fig. 1B).

\section{Analysis of whole-cell patch clamp data}

Analysis of the whole-cell current-clamp recordings was performed using the software Fitmaster (HEKA). The input resistance was calculated from the steady-state voltage response to injected current steps that did not elicit APs by fitting the quadratic equation:

$$
\Delta V=R_{N, 0} \Delta I+C_{A R} \Delta I^{2}
$$

Where $R_{N, O}$ is the voltage-independent input resistance and $C_{A R}$ is the coefficient of anomalous rectification (Waters and Helmchen, 2006). The membrane time constant, $\tau$, was estimated by fitting a double exponential to the voltage response of a-300-pA current injection and using the higher value. The rebound potential was measured from a -300-pA current step (if the trace did not include a rebound $A P$ ), as the difference between the maximal value after the end of the stimulus $\left(V_{\max }\right)$ and the baseline measured before the start of the stimulus $\left(V_{\text {baseline }}\right)$. The sag ratio was defined as: 


$$
\text { Sag }=\left(V_{\text {baseline }}-V_{s s}\right) /\left(V_{\text {baseline }}-V_{\text {min }}\right)
$$

where $V_{\min }$ is the minimal value reached after the onset of the stimulus and versus ${ }_{s}$ is the steady-state value of the voltage response to a $-300-p A$ current step. The resting membrane potential $\left(V_{m}\right)$ was estimated by averaging a 10 -s spontaneous recording. The following AP parameters were estimated from the first AP of the rheobase trace (the first trace in the rheobase protocol to elicit an AP): AP threshold (defined as maximum of the double derivative of the voltage response, found using a fit), AP amplitude (difference between maximum amplitude and AP threshold), AP half width (width at $50 \%$ of max AP amplitude), fast afterhyperpolarization potential (fAHP; minimum value directly after AP) and the depolarizing afterpotential (DAP; difference between the maximum value after the AP and the fAHP, in five cells with doublet spikes this could not be measured). The parameters fAHP and DAP were only measured in cells from MEC LII. We calculated AP amplitude, AP width at $0 \mathrm{mV}$ and interspike interval (ISI) as a function of AP number from a positive current step $(+200$ or $210 \mathrm{pA})$, as well as the ratio between the first and the second ISI and the adaptation ratio $\left(I S I_{\text {first }} /\left.I S\right|_{\text {last }}\right)$. To look at the relationship between firing frequency and current, we measured the average firing frequency from current steps ranging from 200-500 pA. We also measured the instantaneous frequency between the two first APs $\left(f_{0}\right)$ and the two last APs (steady state, $f_{s s}$ ). The AHP after the end of the current injection was also measured, for current steps ranging from 50-500 pA. The measures of firing frequencies and AHP as a function of current were only done on a subset of the cells, and for MEC this dataset only included cells from the one-monthold animals. Cells that had a $\mathrm{V}_{\mathrm{m}}>-57 \mathrm{mV}, \mathrm{AP}$ amplitude $<75 \mathrm{mV}$ or a bridge balance $>22 \mathrm{M} \Omega$ were excluded from the analysis, as well as putative interneurons.

The images from the LSCM were used to classify the neurons based on morphology. Cells in LEC LII that had a clear pyramidal $(n=9)$ or multiform $(n=17)$ morphology and cells in MEC LII with a clear pyramidal $(n=7)$ morphology, but not the intermediate cells types, were excluded from the analysis. Some cells were not filled well enough with biocytin to visualize the morphology $(n=9$ for LEC and $n=5$ for MEC). As the vast majority of the cells that were filled sufficiently were classified as fan cells (101 of 127 cells in LECII; $80 \%$ ) or stellate cells (73 of 80 cells in MECII; 91\%), we assumed that most of the nonfilled cells would be of these types, and these were therefore included in the analysis. All the included cells from MEC displayed the known typical electrophysiological properties of stellate cells, including prominent sag and rebound.

\section{Statistical analysis}

The quantitative VSDI data obtained in DG and MEC, was analyzed with respect to effect of genotype within each age group using a linear mixed model. Fixed factors were sex, genotype (+/+ or wild type) and where relevant, area (exposed and enclosed blade of DG) or distance from electrode in MEC, as well as the interaction between genotype and area/distance from electrode. A repeated effects variable with a diagonal or compound symmetry covariance structure (chosen based on convergence and information criteria) was included to account for several voxels (the regions of interest) being measured in each slice (intraslice variance).

A linear mixed model was used to estimate the effect of genotype on the measured electrophysiological parameters from the single cell recordings. Rat ID was added as a random effect to account for several cell recordings within one animal, and thus the values from each cell will not be independent. Genotype and age were included as fixed effects with two levels each $(+/+$ and $-/-$; one and three months). In addition, sex and experimental setup was included as a fixed effect to correct for possible differences that might bias the results. An extended model was also run to test for the possible interactions between genotype and age, and genotype and sex. On parameters with several measurements within the same cell (e.g., for several APs or current steps) the AP number or injected current was included as factors and as repeated measures with cell ID as the subject variable. The covariance structure for the repeated measures was compound symmetry or unstructured, based on which one had lower information criteria. The possible interaction between genotype and AP number or genotype and injected current was also included in the statistical model.

No corrections were done for multiple testing and results were considered statistically significant when $p<$ 0.05. IBM SPSS Statistics, version 22 (IBM Corporation; RRID: SCR_002865) was used for the statistical analysis.

\section{Results}

\section{No changes in fan cell physiology in LEC and subtle changes in stellate cell physiology in the MEC in homozygous McGill-R-Thy1-APP rats}

To investigate whether basic electrophysiological properties or firing behavior were altered in the McGill-R-Thy1APP transgenic rat, we performed whole-cell patch-clamp recordings in the current clamp mode of principal cells in Layer II of LEC and MEC in rats aged one and three to four months of age.

We included 111 fan cells from LEC in the electrophysiological analysis ( $n=47$ cells from transgenic animals and $n=64$ cells from control animals; aged one and three to four months). Since iA $\beta$ reportedly aggregates preferentially in LEC close to the rhinal fissure (Kobro-Flatmoen et al., 2016), we selectively recorded fan cells in LEC superficially in Layer II and just ventral to the rhinal fissure, in semicoronal slices (Fig. 2A). Most of them displayed the typical morphology, with apical dendrites fanning out toward the pial surface and only a few or no basal dendrites (Tahvildari and Alonso, 2005; Canto and Witter, 2012a; Fig. 2B). Fan cells showed a low sag and rebound potential, no spike doublets/triplets or DAP, but had a relatively high input resistance and time constant (Fig. 2C; Canto and Witter, 2012a,b). The majority of the fan cells recorded in homozygous $(+/+)$ transgenic rats $(89 \%$; 31 of 35 neurons) stained positive for $\mathrm{i} A \beta$ (Fig. 2G). A few neurons in the $+/+$ animals were not $A \beta$ immunoreactive (four of 35 fan cells; example in Fig. $2 H$ ), whereas in 

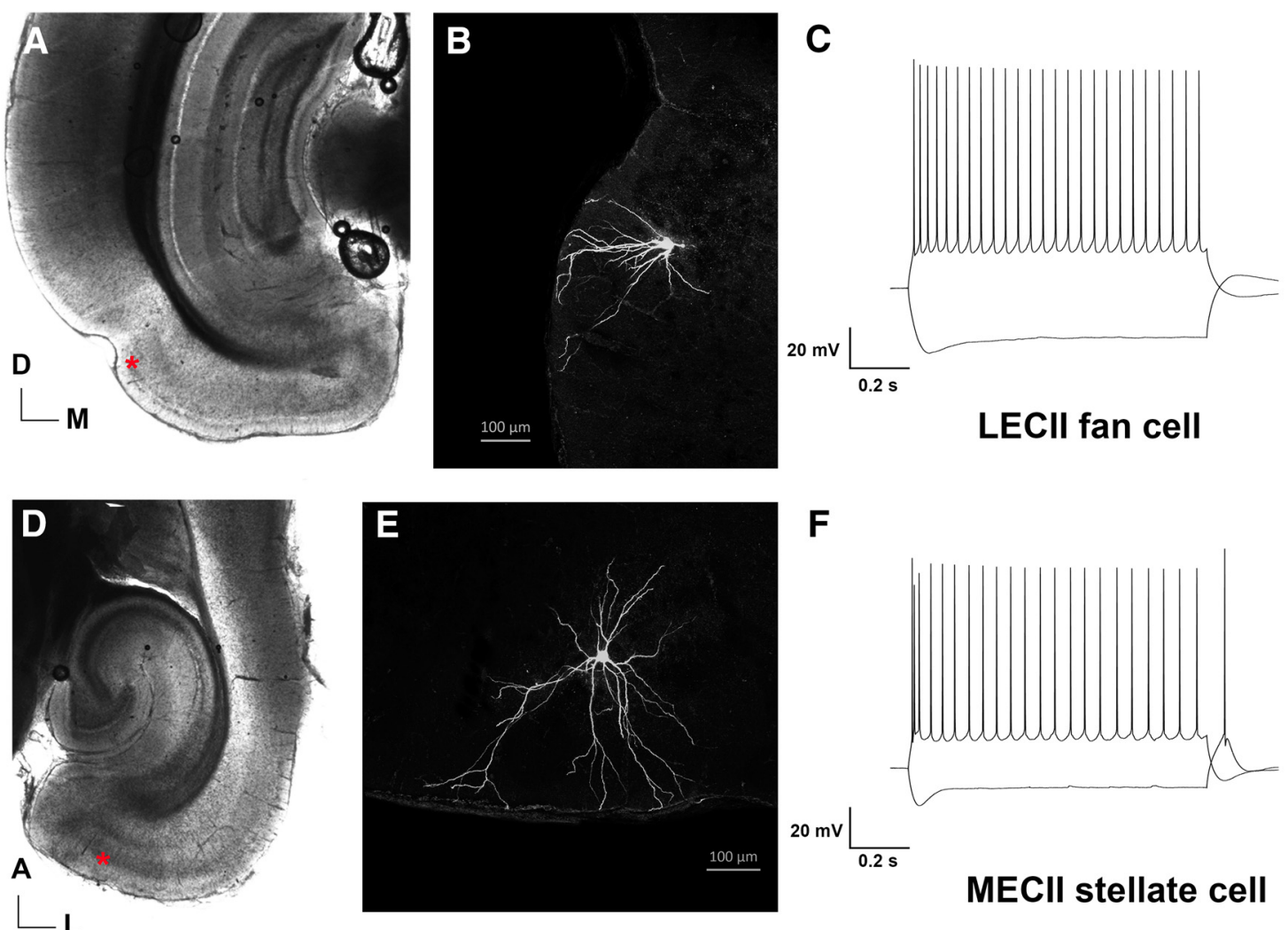

$\mathbf{F}$
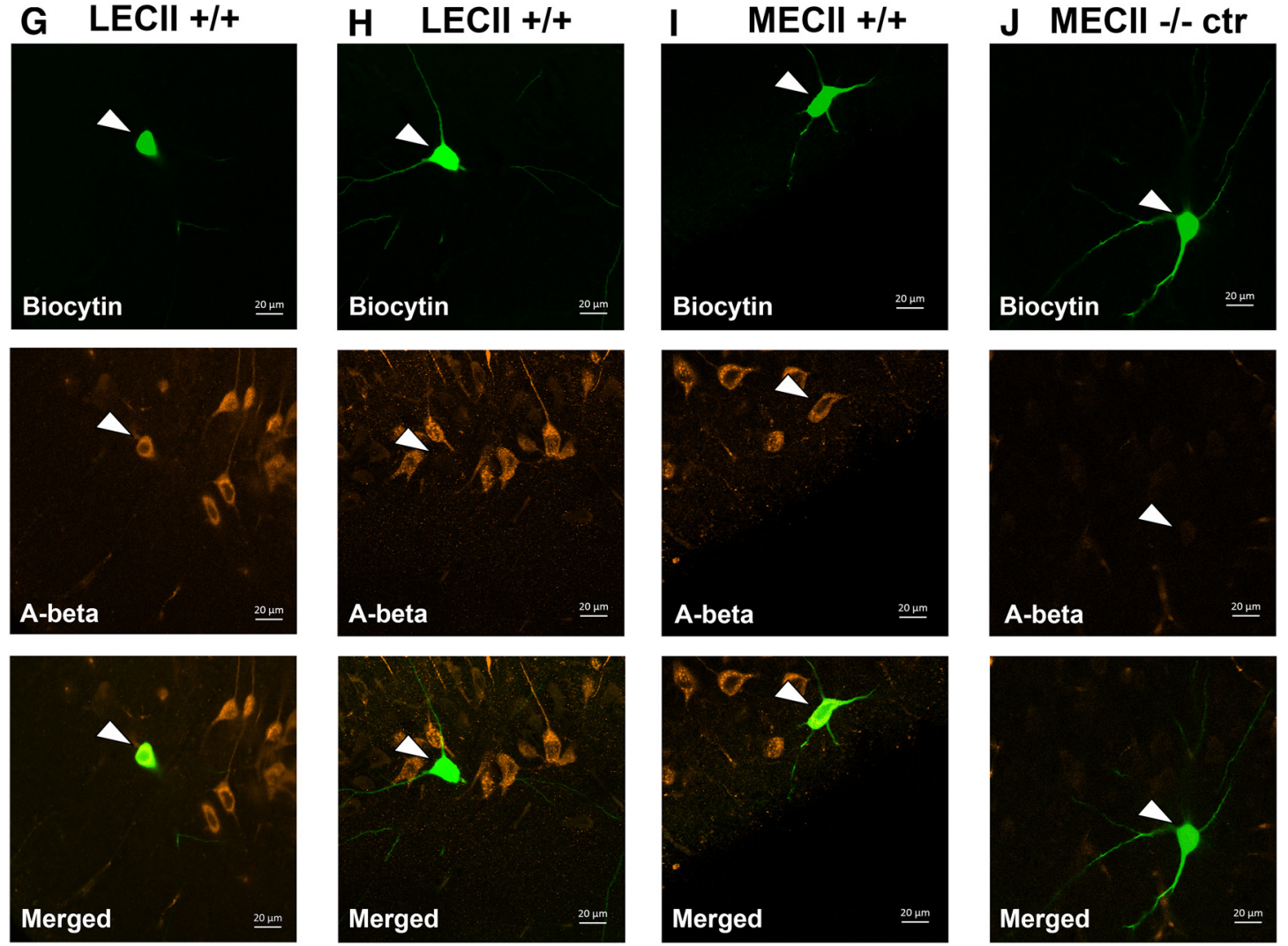

Figure 2. The characteristic morphology and electrophysiology of a fan cell and a stellate cell from EC Layer II and examples of intracellular expression of human $A \beta$ in recorded cell. $\boldsymbol{A}$, Representative example of a semicoronal slice used for recording cells in LEC. The asterisk ventral to the rhinal fissure marks the location of the patched cell shown in $\boldsymbol{B}$. $\boldsymbol{B}$, Confocal image showing the morphology of a typical fan cell in Layer II of LEC, close to the rhinal fissure (location marked in $\boldsymbol{A}$ ). $\boldsymbol{C}$, Trace from the fan cell in $\boldsymbol{B}$ 
continued

showing voltage responses to hyperpolarizing and depolarizing current steps of $\pm 300 \mathrm{pA}$. $\boldsymbol{D}$, Representative example of a horizontal slice used for recording cells in the MEC. The asterisk marks the location of the cell shown in $\boldsymbol{E}$. $\boldsymbol{E}$, Confocal image showing the morphology of a typical stellate cell in Layer II if MEC (location marked in $\boldsymbol{D}$ ). $\boldsymbol{F}$, Trace from the stellate cell in $\boldsymbol{E}$ showing voltage responses to hyperpolarizing and depolarizing current steps of $\pm 300 \mathrm{pA}$. LEC, lateral EC; MEC, medial EC. G, Confocal scan from a three-month-old homozygous McGill-R-Thy1-APP transgenic rat showing a fan cell in LEC LII with iA $\beta$. $\boldsymbol{H}$, Confocal scan from a one-month-old homozygous transgenic rat showing a stellate cell in MEC LII with iA $\beta$. I, Confocal scan from a one-month-old homozygous transgenic rat showing a fan cell in LEC LIl without expression of iA $\beta$. $\boldsymbol{J}$, Confocal scan from a one-month-old negative control animal showing no expression of human $\mathrm{i} A \beta$. The cells were filled with biocytin during recording and visualized with streptavidin labeled with Alexa Fluor 488. The presence of the anti-human A $\beta$ antibody McSA1 was visualized with Alexa Fluor 546. LEC, lateral EC; MEC, medial EC; A, anterior; D, dorsal; L, lateral; M, medial.

negative littermates $(-/-)$ none of the neurons showed immunoreactivity to human $A \beta$.

None of the measured basic electrophysiological or AP parameters of fan cells differed between the transgenic and control animals (Table 1; Extended Data Table 1-1). Similarly, there was no significant effect of genotype on the measured wave form parameters and firing properties (Table 2; Extended Data Table 2-1).

In total, 78 stellate cells in Layer II of MEC were included in the analysis $(n=38$ cells from homozygous transgenic rats and $n=40$ cells from negative littermates, aged one and three to four months). The stellate cells, recorded in horizontal slices, were mainly located super- ficially in Layer II (Fig. 2D), and not at extremes of the mediolateral axis (i.e., not close to the border to parasubiculum or LEC). The majority of the stellate cells displayed the typical morphology, with dendrites radiating from the soma (Fig. 2E), though some cells had intermediate stellate to pyramidal morphologies (Canto and Witter, 2012b; Fuchs et al., 2016). All included cells showed a prominent sag (low sag ratio) and rebound potential, and rebound spikes after a hyperpolarizing pulse were not uncommon (Fig. 2F). In addition spike doublets or triplets could be seen in the start of spiking trains, and a fAHP and DAP was clearly seen after single APs (Canto and Witter, $2012 b)$. When staining for $\mathrm{iA} \beta, 96 \%$ of the recorded stel-

Table 1. Results from the mixed linear model analysis for electrophysiological parameters of LEC II fan cells in homozygous transgenic animals $(+/+)$ and controls $(-/-)$

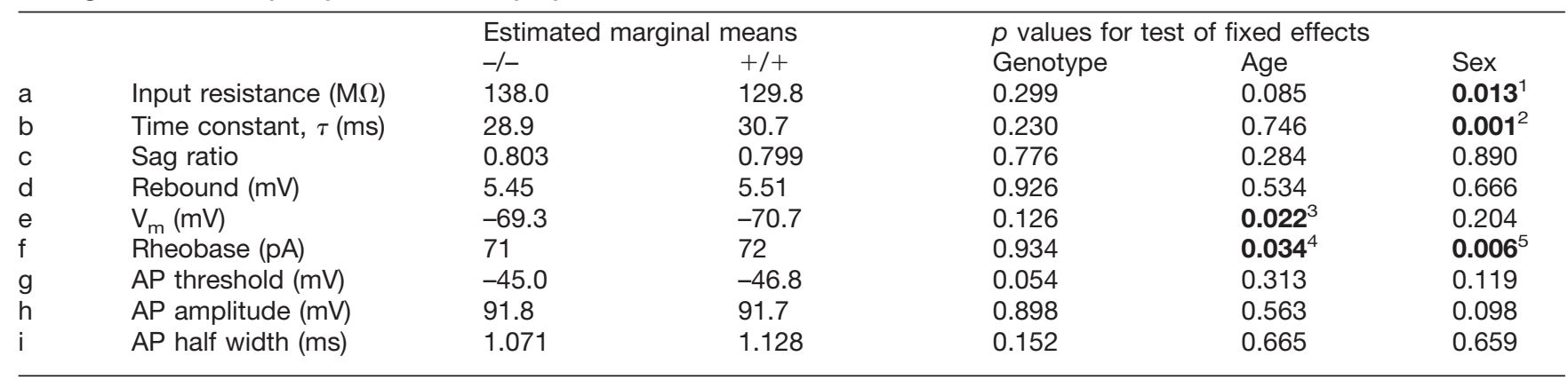

Basic electrophysiological and AP properties from all individual cells are represented in Extended Data Table $1-1 ; n=111$ cells from 40 animals. $V_{\mathrm{m}}$, resting membrane potential. Values printed in bold face identify significance.

${ }^{1}$ Effect size: $21.9 \mathrm{M} \Omega$ (males higher). ${ }^{2}$ Effect size: $5.6 \mathrm{~ms}$ (males higher). ${ }^{3}$ Effect size: $-2.2 \mathrm{mV} .{ }^{4}$ Effect size: $18.9 \mathrm{pA} .{ }^{5} \mathrm{Effect}$ size: $24.5 \mathrm{pA}$ (males lower).

Table 2. Estimated $p$ values for AP parameters as a function of AP number and firing properties of LEC LII fan cells

\begin{tabular}{lllllll}
\hline & & Genotype & Age & Sex & AP no. & AP $\times$ genotype \\
a & AP amplitude & 0.855 & $\mathbf{0 . 0 0 2 ^ { 1 }}$ & $\mathbf{0 . 0 2 4 ^ { 2 }}$ & $\mathbf{0 . 0 0 0}$ & 0.059 \\
b & AP width & 0.388 & 0.195 & 0.620 & $\mathbf{0 . 0 0 0}$ & 0.123 \\
c & ISI & 0.166 & 0.124 & $\mathbf{0 . 0 3 9}^{3}$ & $\mathbf{0 . 0 0 0}$ & 0.317 \\
d & ISI1/ISI2 & 0.698 & $\mathbf{0 . 0 0 7 ^ { 4 }}$ & $\mathbf{0 . 0 0 6 ^ { 5 }}$ & - & - \\
e & Adaptation ratio & 0.957 & 0.237 & $\mathbf{0 . 0 1 4 ^ { 6 }}$ & - & - \\
& & Genotype & Age & Sex & Current & Current $\times$ genotype \\
f & Average frequency, $f$ & 0.554 & 0.634 & 0.577 & $\mathbf{0 . 0 0 0}$ & 0.425 \\
g & $f_{O}$ & 0.936 & 0.334 & 0.122 & $\mathbf{0 . 0 0 0}$ & 0.157 \\
h & $f_{\text {sS }}$ & 0.666 & 0.650 & 0.578 & $\mathbf{0 . 0 0 0}$ & 0.977 \\
i & AHP & 0.774 & 0.659 & 0.434 & $\mathbf{0 . 0 0 0}$ & 0.656
\end{tabular}

AP and firing properties of LEC LII fan cells in homozygous transgenic rats $(+/+)$ and control animals $(-/-)$ are shown in Extended Data Table 2-1. Values are estimated $p$ values from the mixed linear model, $n=111$ cells from 40 animals; for firing frequencies and AHP $n=67$ cells from 26 animals. ISI, interspike interval; adaptation ratio, first ISI/last ISI; $f_{o}$, instantaneous firing frequency between two first APs; $f_{s S}$, instantaneous firing frequency between two last APs. Values printed in bold face identify significance.

${ }^{1}$ Effect size: $2.5 \mathrm{mV} .{ }^{2}$ Effect size: $1.7 \mathrm{mV}$ (males lower). ${ }^{3}$ Effect size: $9.8 \mathrm{~ms}$ (males higher). ${ }^{4}$ Effect size: $-0.07 .{ }^{5} \mathrm{Effect}$ size: 0.07 (male higher). ${ }^{6}$ Effect size: 0.08 (male higher). 
Table 3. Estimated marginal means and $p$ values for electrophysiological parameters of MEC II stellate cells

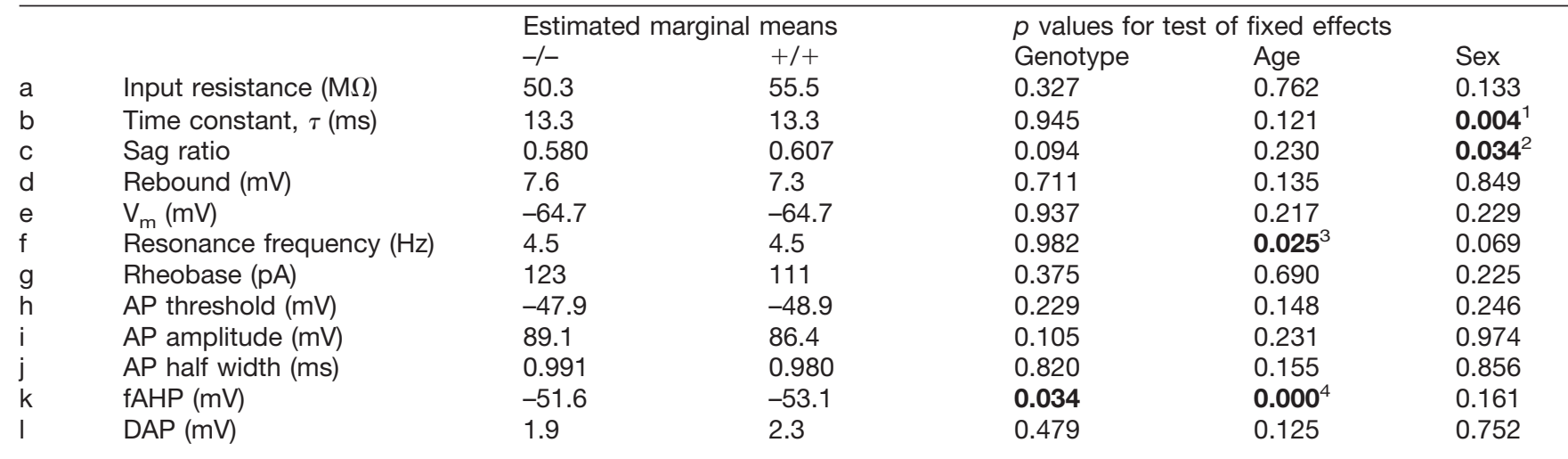

Basic electrophysiological properties of MEC LII stellate cells in homozygous transgenic rats $(+/+)$ and negative control animals $(-/-)$ for all cells are provided in Extended Data Table 3-1. Values are estimated marginal means and $p$ values from the mixed linear model, $n=78$ cells from 30 animals. $V_{m}$, resting membrane potential. Values printed in bold face identify significance.

${ }^{1}$ Effect size: $2.2 \mathrm{~ms}$ (males lower). ${ }^{2}$ Effect size: 0.026 (males higher). ${ }^{3}$ Effect size: $-0.65 \mathrm{~Hz} .{ }^{4} \mathrm{Effect}$ size: $-4.0 \mathrm{mV}$.

late cells in slices from transgenic were $A \beta$ immunoreactive (25 of 26 cells; example in Fig. 2/). No $\mathrm{A} \beta$-immunoreactive neurons were observed in the control slices (Fig. 2J).

Of all the electrophysiological properties measured in stellate cells, two parameters were altered in transgenic compared to control rats (Tables 3, 4; Extended Data Tables 3-1, 4-1). The fAHP displayed a slight but significantly increased hyperpolarization in the homozygous $+/+$ rats compared to the controls (Table 3 , row $k$ ), and $\mathrm{f}_{0}$ was also significantly increased in the $+/+$ transgenic rats (Table 4, row g; estimated effect $36.2 \mathrm{~Hz}$ ).

In the statistical model, age and sex were included as fixed effects, and on several of the electrophysiological parameters these had significant effects (Tables 1-3). In this study, the aim was to investigate the effects of genotype, but these results for age and sex underline the importance of including these as factors in the statistical analyses.

\section{VSDI and $A \beta$ immunoreactivity of the hippocampal region}

In view of the minor increase in excitability observed in Layer II stellate cells in MEC, combined with the fact that these neurons provide major inputs to the DG (Cappaert et al., 2015), we decided to record the propagation of neural activity in the hippocampal region using VSDI in acute brain slices of McGill-R-Thy1-APP and wild-type rats (Fig. 1). Bipolar electrical stimulation was applied to the DG and MEC (Fig. 3A, areas shown with red asterisks). The slices used for VSDI were also immuno-stained for $\mathrm{A} \beta-42$ and showed that in wild-type animals staining was absent (Fig. 3B,D,E), whereas every transgenic animal in all age groups (three, nine, and 12 months) had strong iA $\beta$ immunoreactivity in several areas of the hippocampal region (Fig. $3 C, F, G$ ). Expression was particularly strong in the pyramidal cell layer of subiculum (Fig. 3F), CA1, CA3 (Fig. 3C) as well as in Layer II of the EC (Fig. 3G). No extracellular plaques were seen in any of the slices from animals aged three or nine months, whereas at 12 months, the plaque levels were highly variable, from no plaques to very high plaque loads (Heggland et al., 2015).

\section{The neural network responses in the two blades of DG show subtle alterations in transgenic rats}

Stimulation in the molecular layer in the crest of $D G$, the area bridging the two blades, with a single pulse $(0.2 \mathrm{~mA}$ for $300 \mu \mathrm{s})$, resulted in activation in both of the blades of DG as well as in the hilus, and in several cases, a small change in the optical signal could also be seen in CA3

Table 4. Estimated $p$ values for AP parameters as a function of AP number and firing properties of MEC LII stellate cells

\begin{tabular}{lllllll}
\hline & & Genotype & Age & Sex & AP no. & AP $\times$ genotype \\
a & AP amplitude & 0.318 & 0.463 & 0.812 & $\mathbf{0 . 0 0 0}$ & 0.258 \\
b & AP width & 0.264 & 0.670 & 0.246 & $\mathbf{0 . 0 0 0}$ & 0.589 \\
c & ISI & 0.576 & 0.593 & 0.977 & $\mathbf{0 . 0 0 0}$ & 0.685 \\
d & ISI1/ISI2 & 0.449 & 0.657 & 0.416 & - & - \\
e & Adaptation ratio & 0.818 & 0.737 & 0.862 & - & - \\
& & Genotype & Age & Sex & Current & Current $\times$ genotype \\
f & Average frequency, $f$ & 0.611 & - & 0.829 & $\mathbf{0 . 0 0 0}$ & 0.884 \\
g & $f_{O}$ & $\mathbf{0 . 0 4 2}$ & - & 0.332 & $\mathbf{0 . 0 0 0}$ & 0.884 \\
h & $f_{S S}$ & 0.839 & - & 0.870 & $\mathbf{0 . 0 0 0}$ & 0.984 \\
i & AHP & 0.561 & - & 0.629 & $\mathbf{0 . 0 0 0}$ & 0.922
\end{tabular}

Values are estimated $p$ values from the mixed linear model, $n=78$ cells from 30 animals; for firing frequencies and AHP $n=38$ cells from 16 animals. ISI, interspike interval; adaptation ratio, first ISI/last ISI; $f_{O}$, instantaneous firing frequency between two first APs; $f_{s s}$, instantaneous firing frequency between two last APs. Values printed in bold face identify significance. 
A

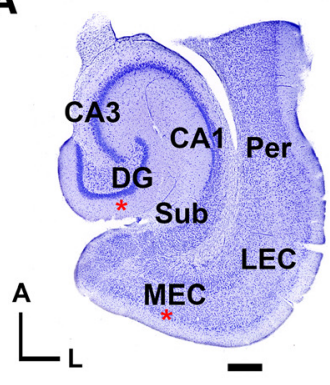

B
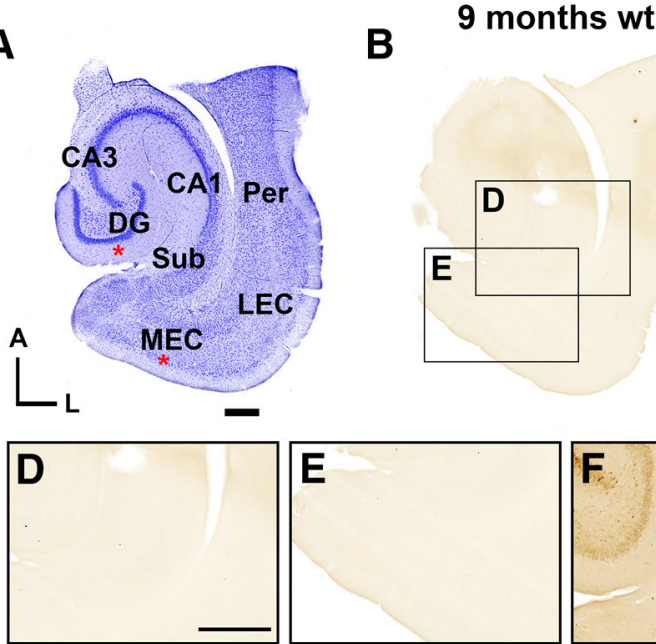

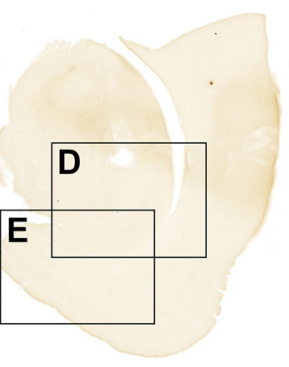

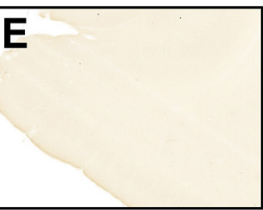

C

\section{2 months $+/+$}

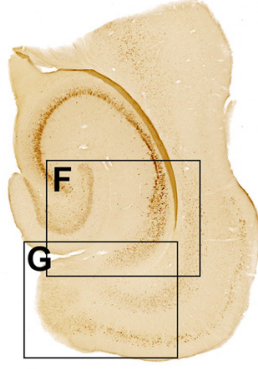

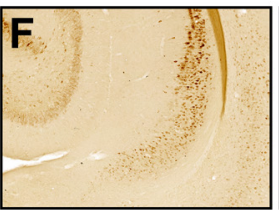

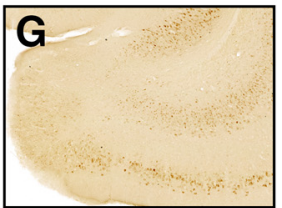

Figure 3. Horizontal slices from control animals and homozygous McGill-R-Thy1-APP rats were used for VSDI. $\boldsymbol{A}$, Example of a horizontal slice stained with cresyl violet showing the different areas targeted for stimulation (red asterisks). $\boldsymbol{B}$, Example slice from a nine-month-old wild-type rat showing no immunoreactivity against $A \beta$, using the human-specific anti-A $\beta$ antibody McSA1. $C$, Example slice from a 12-month-old homozygous transgenic rat with iA $\beta$ immunoreactivity. Insets show higher magnification of the subiculum $(\boldsymbol{D}, \boldsymbol{F})$ and the MEC $(\boldsymbol{E}, \boldsymbol{G})$. Scale bars: $500 \mu \mathrm{m}$ (bar in $\boldsymbol{A}$ represents all overview images, bar in $\boldsymbol{D}$ all insets). CA3 and CA1, subfields of the hippocampus; Sub, subiculum; Per, perirhinal cortex.

(Fig. 4). In the wild-type animals, the exposed blade (also called the outer, free, or infrapyramidal blade) had a higher level of activity than the enclosed blade (also called the inner or suprapyramidal blade), at all ages (Fig. 4, left panels). In the homozygous transgenic animals, this pattern of activation was also seen in the majority of the slices at three and nine months (Fig. 4, right panels). However, at 12 months of age, we observed that some

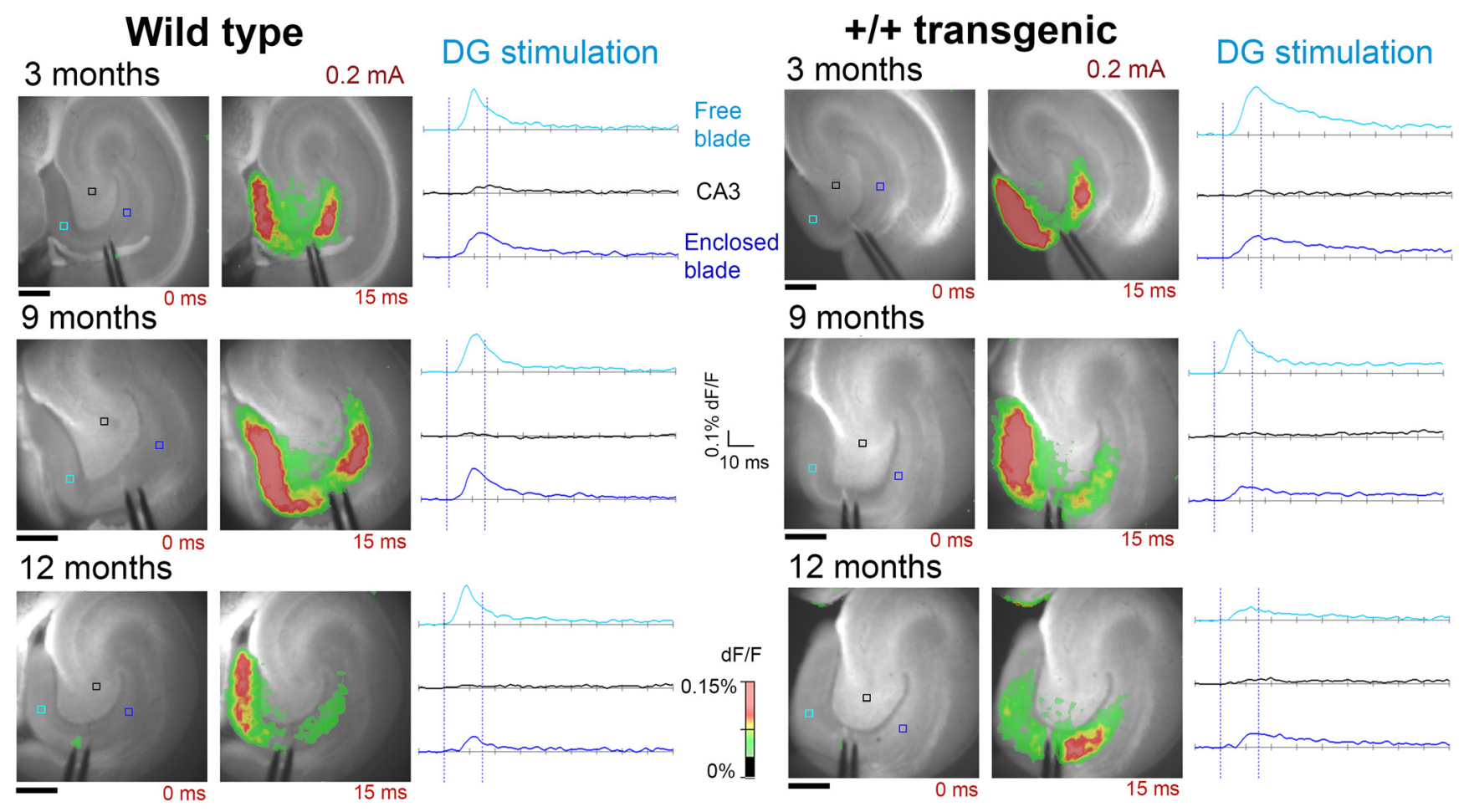

Figure 4. VSDI of DG showed differences in activation patterns in control and transgenic animals. Evoked activity from a bipolar stimulation electrode (single 0.2-mA pulse) centered in DG in control (left) and transgenic (right) animals. The activity spread to both blades, and in some cases, activity could also be seen in CA3. At three and nine months, the membrane potential changes were in general larger in the exposed blade than the enclosed blade. In contrast, at 12 months, several of the transgenic animals showed an increased activity in the inner blade. Images are from representative horizontal slices from wild-type and $+/+$ transgenic animals at three, nine, and 12 months of age. Scale bars: $500 \mu \mathrm{m}$. 
A

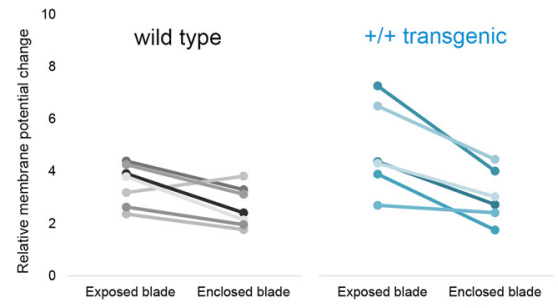

9 months

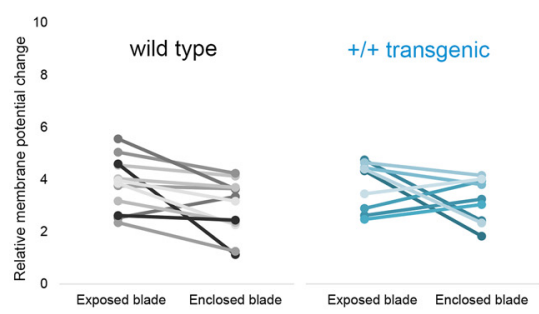

\section{2 months}

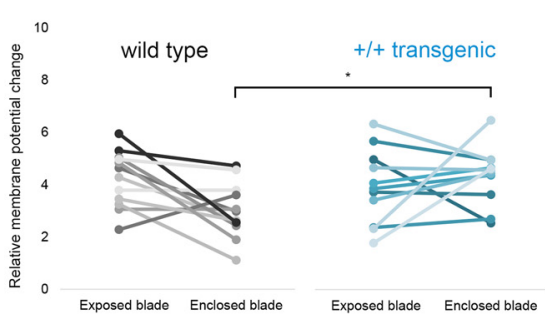

B
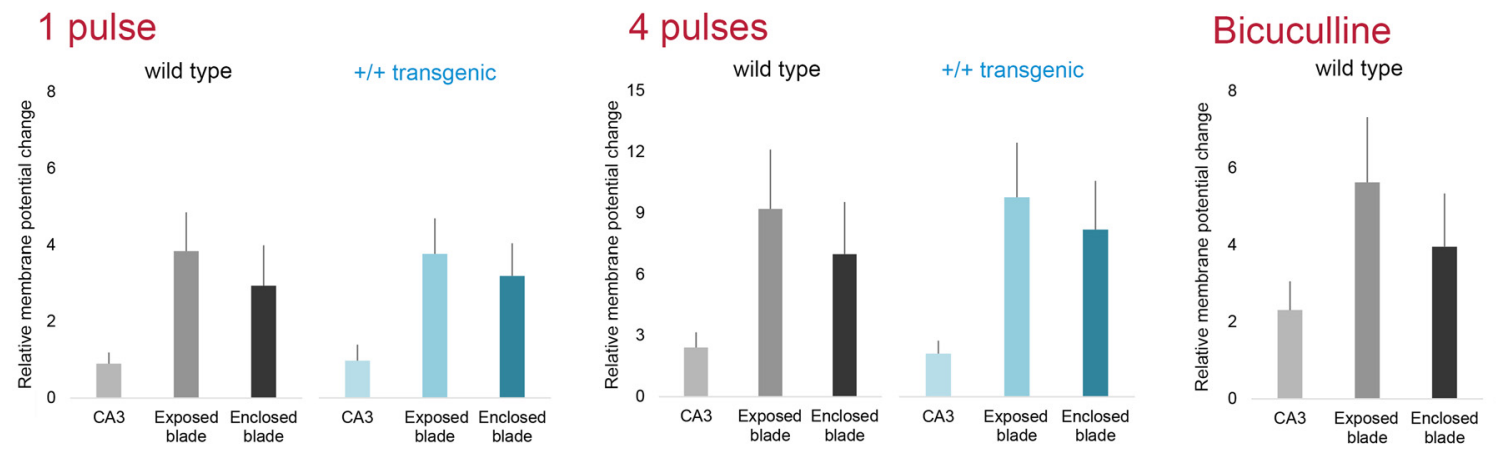

9 months

+/+ transgenic

4 pulses
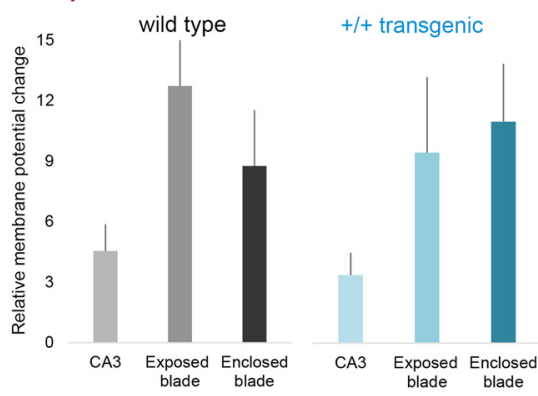

12 months

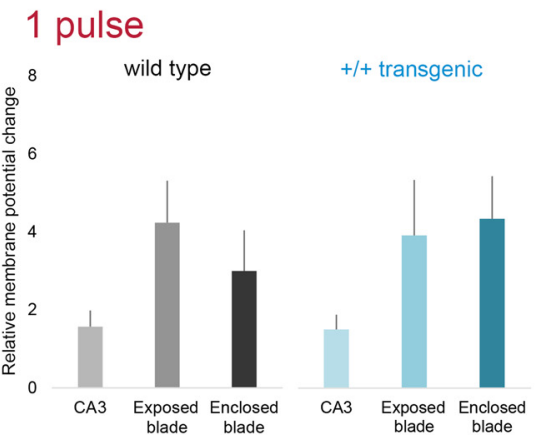

Bicuculline

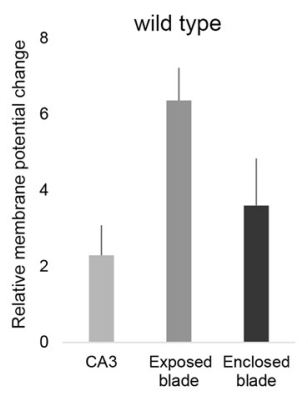

+/+ transgenic

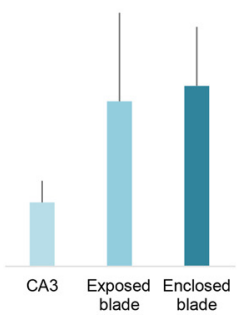

Figure 5. The evoked activity in the two blades of DG was significantly altered in 12-month-old transgenic animal, with increased activity in the enclosed blade, with a constant overall activated area. $\boldsymbol{A}$, Quantification of the relative membrane potential change measured with VSDI in the two blades of DG (ROI are the voxels shown in Fig. 3) is shown for three, nine, and 12 months. In control animals, the majority of the slices had larger membrane potential changes in the exposed blade than the enclosed blade, but at 12 months, this pattern was altered in a portion of the transgenic animals, while the total activated area was similar in all age groups. Values from singles slices are shown. Asterisk indicates estimated marginal means that have non-overlapping $95 \%$ confidence intervals. B, Quantification of the relative membrane potential change measured with VSDI in the two blades of DG and CA3 in transgenic and control animals after a single or four-pulse stimulation and in the presence of $5 \mu \mathrm{M}$ bicuculline at nine and 12 months. At nine months, the pattern of activation was similar in transgenic and control animals (top panels), but at 12 months, this pattern was altered in the $+/+$ transgenic group (bottom panels). Mean values are shown, with bar representing standard deviation. For each age group the effects of genotype and area and the interaction was tested with a linear mixed model. Results from the statistical analysis are shown in Extended Data Figure 5-1.

transgenic rats had larger responses in the enclosed than the exposed blade or very similar responses in the two blades after stimulation in the crest (Fig. 4, lower right panel).

Quantification of the membrane potential changes were in line with this altered pattern of DG activation, following single pulse stimulation (Fig. 5; Extended Data Fig. 5-1). At three and nine months, there was a larger membrane potential change in the exposed blade than the enclosed blade in both wild-type and control animals (Fig. 5A, left and middle panel). The statistical analysis, using the mixed linear model, showed a significant effect of area (blade) at three and nine months, but no significant effect of genotype or interaction between area and genotype (Extended Data Fig. 5-1, rows a, b). At 12 months, the effect of area was no longer significant, nor was there a main effect of genotype (Extended Data Fig. 5-1, row c). However, at 12 months, there was a significant interaction between genotype and area (Extended Data Fig. 5-1, row c), and the membrane potential changes in the enclosed 
Table 5. Results from the mixed linear model for total number of activated pixels and PPR using VSDI in the DG of homozygous transgenic animals $(+/+)$ and controls (-/-)

\begin{tabular}{|c|c|c|c|c|c|}
\hline & \multicolumn{2}{|l|}{ Mean (SD) } & \multicolumn{3}{|c|}{$p$ values for test of fixed effects } \\
\hline \multicolumn{6}{|c|}{$\begin{array}{l}\text { Activated pixels } \\
\text { (1 pulse) }\end{array}$} \\
\hline 3 months & $807(284)$ & $83(297)$ & 0.549 & 0.463 & $13 / 7$ \\
\hline 9 months & $1698(579)$ & $1800(279)$ & 0.641 & 0.638 & $21 / 10$ \\
\hline 12 months & $1687(485)$ & $1581(427)$ & 0.564 & 0.733 & $23 / 9$ \\
\hline 12 months & $0.920(0.119)$ & $0.854(0.098)$ & 0.190 & 0.718 & $23 / 9$ \\
\hline \multicolumn{6}{|c|}{ PPR: bicuculline } \\
\hline 9 months & $1.320(0.076)$ & $1.321(0.082)$ & 0.970 & 0.897 & $15 / 8$ \\
\hline 12 months & $1.373(0.088)$ & $1.363(0.070)$ & 0.859 & 0.782 & $15 / 9$ \\
\hline
\end{tabular}

blade were significantly higher in the homozygous transgenic animals than in the wild-type animals (Fig. $5 \mathrm{~A}$, right panel). The same pattern of activation in DG was also found when stimulating with four pulses at $40 \mathrm{~Hz}$, and with the addition of the GABAa antagonist bicuculline (Fig. 5B, middle and right panels). The statistical test showed comparable results, with a significant interaction between genotype and area at 12, but not nine, months (Extended Data Fig. 5-1, rows $d-g$ ).

In all age groups, the total activated area (number of pixels) was unaltered in the $+/+$ transgenic rats compared to wild type (Table 5). In addition, there was no significant difference between the PPR in wild-type and $+/+$ transgenic animals at either nine or 12 months (Table 5). The addition of bicuculline did not change this pattern of activation. This indicates that although there was a change in the activation pattern of DG in the homozygous transgenic animals at 12 months, the overall excitability of the DG circuitry was not altered.

\section{Transient changes in neural network responses in MEC in transgenic rats}

Layer II neurons in MEC that project to the hippocampus, also give rise to local axon collaterals in Layer I and $\mathrm{II}$, reaching for around $300 \mu \mathrm{m}$ with an occasional spread of up to $400 \mu \mathrm{m}$ along the transverse axis (Tamamaki and Nojyo, 1993; Klink and Alonso, 1997; Schmidt et al., 2017). These local collaterals may innervate neurons in
Layers II, III, and V, since all have apical dendrites in Layers I/II. We therefore aimed to look at differences in local network responses between wild-type and transgenic animals on stimulation in Layer II in MEC using VSDI.

Stimulation in superficial MEC (single 0.6-mA pulse) led to changes in the VSDI signal that spread in the superficial layers as well as to the deep layers of MEC (example image in Fig. 1A). In addition, small changes were observed in the pre- and parasubiculum and DG in many slices. We analyzed changes in fluorescent signal in individual voxels taken at the position of the stimulation electrode and gradually moving away with a maximum distance of $\sim 700 \mu \mathrm{m}$ away from the electrode. As expected, a significant effect of distance from electrode was seen, with a decreasing signal with distance both across and within layers (Table 6; Extended Data Table 6-1). No main effect of genotype was observed for any age group (Table 6). However, at three months, there was a significant interaction between genotype and distance from electrode across layers, but this was not seen at nine and 12 months (Table 6). Similarly, a small but significant interaction between genotype and distance from electrode within layers was seen at nine months, but not three and 12 months (Table 6). These significant interactions indicate alterations in the network responses in the MEC of the transgenic rats. However, the effects are small and transient, as they are only seen in single age groups.

Table 6. Results from the mixed linear model for quantified membrane potential change using VSDI in MEC of homozygous transgenic animals $(+/+)$ and controls (-/-)

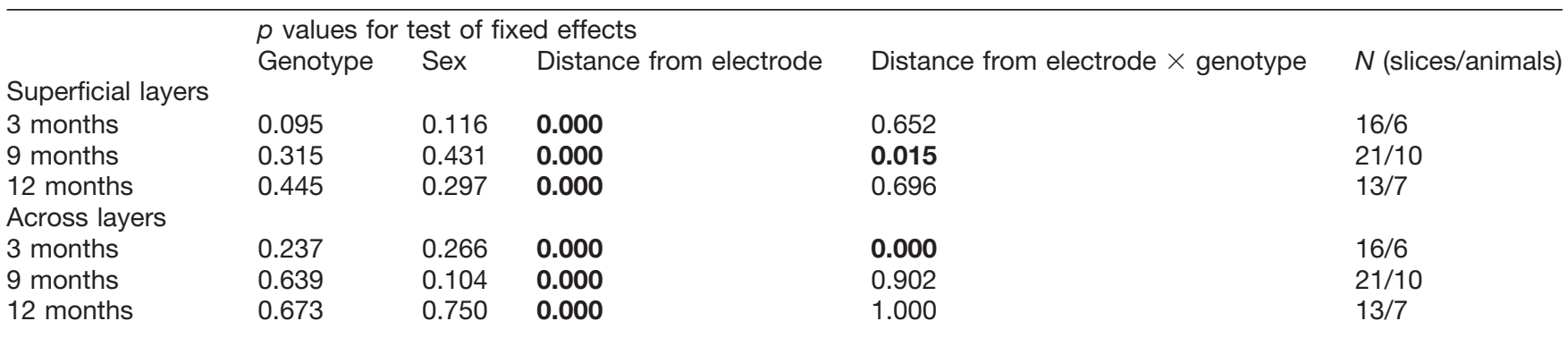

Spread of activity from electrode placed in superficial layers MEC recorded with VSDI for all rats is shown in Extended Data Table 6-1. Values printed in bold face identify significance. 


\section{Discussion}

Accumulating evidence suggests that the cognitive symptoms of memory loss and learning impairments in the early stages of $A D$ are not mainly due to neuronal loss or atrophy, but can be linked to neuronal and synaptic dysfunction and subsequent abnormal patterns of activation in local neuronal circuits and larger-scale networks (D'Amelio and Rossini, 2012). A $\beta$ peptides likely play an important role in these deleterious processes by affecting synapses and synaptic function (Palop and Mucke, 2010b). Here, we studied changes in the entorhinalhippocampal network and single cells in acute slices taken from McGill-R-Thy1-APP transgenic rats expressing human mutated APP. We first analyzed the electrophysiological properties and excitability of the main principal cell populations in Layer II of EC, fan cells and stellate cells, with the use of in vitro whole-cell patch clamp. When comparing transgenic rats and controls, at one month and three to four months of age, we found no alterations in any of the passive membrane properties, and only subtle differences in the excitability of stellate cells. Further, with the use of VSDI, we observed alterations in the activation patterns of the two blades of DG in 12-month-old homozygous transgenic animals, as well as transient changes in the local network activity in MEC.

Other studies report network hyperexcitability, including seizures, in different brain areas of several mouse models of AD (Palop et al., 2007; Minkeviciene et al., 2009; Harris et al., 2010; Verret et al., 2012), including EC (Duffy et al., 2015; Xu et al., 2015) and DG (Hazra et al., 2013). In the current study, we did not find clear evidence for generalized hyperexcitability of EC or DG in the McGill rat using VSDI in slices. This apparent discrepancy likely is caused by the different experimental methods used. The optical signals we recorded represent the averaged membrane voltage changes in the total population of cells, including glial cells. An increased number of hyperactive as well as hypoactive neurons has previously been reported in $\mathrm{AD}$ mice using $\mathrm{Ca}^{2+}$ imaging (Busche et al., 2008,2012 ). Such changes in single cells or ensembles would sum together and would therefore be difficult, if not impossible, to detect with VSDI. In addition, many of the studies reporting aberrant network activity in transgenic $A D$ models have been done in vivo, with techniques including EEG (Minkeviciene et al., 2009; Verret et al., 2012), single neuron (Kellner et al., 2014), or local field potential recordings (Xu et al., 2015). Thus, we cannot exclude the possibility that in vivo recordings or using a different method to assess network function might reveal other changes in the McGill-R-Thy1-APP rat not seen in the present study.

We found no alterations of subthreshold intrinsic properties in either fan cell or stellate cells in the homozygous transgenic McGill rats aged one and three to four months. In Tg2576 mice, fan and stellate cells in EC showed no changes in the input resistance and resting membrane potential (Marcantoni et al., 2013), in agreement with our findings. Similar results with no changes in subthreshold properties have been shown in pyramidal cells in CA1 of the McGill rat (Qi et al., 2014), PSAPP (Brown et al., 2011),
PDAPP (Kerrigan et al., 2014), 3xTg-AD (Scala et al., 2015), and CRND8 mice (Wykes et al., 2012) as well as in the frontal cortex of APPswe/PS1dE9 (APdE9) mice (Kellner et al., 2014). In contrast, a depolarization of the resting membrane potential has been found in interneurons in DG and pyramidal cells in neocortex in APdE9 mice (Minkeviciene et al., 2009; Hazra et al., 2013) in addition to parvalbumin-positive interneurons, but not pyramidal cells in parietal cortex of hAPPJ20 mice (Verret et al., 2012), suggesting that cell populations might be differentially affected.

We identified two suprathreshold properties that showed alterations in stellate cells in the homozygous rats. Stellate cells display a clear fAHP followed by a DAP (Alonso and Klink, 1993), and this fAHP is due to a Ca ${ }^{2+}$ dependent $\mathrm{K}^{+}$conductance (Storm, 1987; Klink and Alonso, 1993). This conductance is thought to be mediated by BK (big potassium) channels, and is also important for spike repolarization (Sah, 1996). The BK channels can facilitate high-frequency firing, likely through limiting the activation of other potassium channels and decreasing the inactivation of sodium channels (Gu et al., 2007). Notably, the BK current is transient, inactivating rapidly, and thus will be most influential in the initial part of a spike train (Shao et al., 1999). Correspondingly, the other alteration we observed in stellate cells in the transgenic rats was increased excitability early in the spike train, a slightly higher $f_{O}$ at one month. It is thus possible that the hyperexcitability we here describe in the MEC stellate cells in the McGill rat actually results from early changes in ion conductances, in particular the BK potassium current, which might worsen over time. Whether the BK channel, or other channels, is affected specifically in this model will be of interest for further studies. Several studies report various physiologic alterations of single cells in other transgenic mouse models, including changes in excitability, potassium currents and AP wave form (Brown et al., 2011; Wykes et al., 2012; Kerrigan et al., 2014; Scala et al., 2015), highlighting several possible channels as targets for $A \beta$ toxicity.

The VSDI data indicate an alteration of the response pattern in DG, seen in the 12-month homozygous transgenic group, but not at three and nine months. The McGill-R-Thy1-APP rat initially displays extracellular plaques at around nine months, and although the pattern of plaque deposition is similar across animals, the age of onset and temporal progression of the plaque pathology varied considerably between animals (Heggland et al., 2015). This corresponds to the findings in the current study, with highly variable levels of plaque in the recorded slices from the different homozygous transgenic animals. It is of interest to mention that one animal with the highest plaque load also had the largest change in DG activation pattern. In $A D$ mice models, hyperactive neurons have been found to be associated with plaques (Busche et al., 2008,2012 ) and deficits in place cell firing were related to hippocampal plaque burden in the Tg2576 model (Cacucci et al., 2008). Consistent with this are findings that synaptic density is reduced in proximity to plaques (Dong et al., 2007) and neurons in contact with plaques have a 
loss of perisomatic GABAergic synapses (Garcia-Marin et al., 2009), providing a possible mechanism for some of the observed network changes in AD models.

The observed responses after stimulation in the molecular layer of DG, which is a major area of termination of the perforant path input from Layer II of EC, revealed an asymmetry in the activation of the two blades in wild-type animals, with larger amplitudes in the exposed (infrapyramidal) blade than in the enclosed (suprapyramidal) blade. A similar asymmetry has been reported previously with VSDI in rats (Scharfman et al., 2002; Wright and Jackson, 2014) and $\mathrm{Ca}^{2+}$ imaging in mice (Yu et al., 2013). The inhibitory circuitry differs in the two blades (Seress and Pokorny, 1981), which could be a possible explanation for these observations. However, the asymmetry, as well as the alterations seen in the 12-month transgenic group, were seen using both normal ACSF and after addition of the $\mathrm{GABA}_{\mathrm{A}}$ receptor antagonist bicuculline. This indicates that differences or alterations in inhibition do not play a major role in this case, although effects of $\mathrm{GABA}_{B}$ cannot be completely ruled out. Other known blade differences include the perforant path input from the EC, with the two blades receiving preferential input from different parts of EC (Wyss, 1981; Witter et al., 1989). Although the precise distribution of the perforant path to the two blades is somewhat disputed (Witter et al., 1989), these anatomic differences might play a role in the asymmetric activation of DG.

Although possible sex differences were not the focus of this study, the observed effects do support the inclusion of sex as a factor in future studies. In the statistical analysis of the electrophysiological parameters, we included age and sex as factors, both to be able to account for possible bias on the estimated effect of genotype, as well as the possibility that genotype had a differential effect on either sex or with increasing age. Women are at higher risk of developing $A D$ ( $\mathrm{Li}$ and Singh, 2014) and sex differences have been described in other animal models of AD (Wang et al., 2003). An effect of sex on changes in metabolism has been described in the McGill-R-Thy1APP rat (Nilsen et al., 2014), although no clear differences were reported between males and females regarding plaque pathology (Heggland et al., 2015) or memory impairments (Leon et al., 2010). Some of the possible effects we find here might be due to different, and fluctuating, hormone levels, but also differences in genes and gene expression between sexes could play a part (Shah et al., 2014) The effects seen with age were also in general minor. Since we recorded in rats aged one month (juvenile) and three to four months (adult), the changes could reflect the transition to adulthood. Previously, stellate cells in MEC of young adult (postnatal day 46) rats have been shown to be less excitable, and have slight alterations in intrinsic electrophysiological properties, compared to juvenile (postnatal day 21) rats (Boehlen et al., 2010).

In summary, we found that in young animals, there were only minor alterations in the intrinsic electrophysiological parameters of single cells, with a slight hyperexcitability seen in stellate cells and no changes in the fan cells in the homozygous rats, although the majority of these cells displayed accumulation of iA $\beta$. Following up on this, we found that the networks of DG and MEC were largely unaltered in the McGill-R-Thy1-APP transgenic rat. However, at 12 months, there was a statistically significant change in the typically asymmetric activation of the DG seen in wild-type rats. Additionally, there were transient changes in the local network of MEC. Whether the hyperexcitability of stellate cells plays a major role in the cognitive deficits seen in pre-plaque homozygous McGill rats still remains an open question. Additionally, the results from the VSDI point to the possible involvement of the medial perforant path to the $D G$ in $A D$ dysfunction. Even small alterations in the EC-DG or intrinsic DG circuitry could therefore perturb the normal hippocampal processing and thus affect learning and memory.

\section{References}

Alonso A, Klink R (1993) Differential electroresponsiveness of stellate and pyramidal-like cells of medial entorhinal cortex layer II. J Neurophysiol 70:128-143. CrossRef Medline

Bayer TA, Wirths O (2010) Intracellular accumulation of amyloid-beta - a predictor for synaptic dysfunction and neuron loss in Alzheimer's disease. Front Aging Neurosci 2:8. CrossRef Medline

Billings LM, Oddo S, Green KN, McGaugh JL, LaFerla FM (2005) Intraneuronal Abeta causes the onset of early Alzheimer's diseaserelated cognitive deficits in transgenic mice. Neuron 45:675-688. CrossRef Medline

Boehlen A, Heinemann U, Erchova I (2010) The range of intrinsic frequencies represented by medial entorhinal cortex stellate cells extends with age. J Neurosci 30:4585-4589. CrossRef Medline

Braak H, Braak E (1991) Neuropathological stageing of Alzheimerrelated changes. Acta Neuropathol 82:239-259. CrossRef Medline

Brown JT, Chin J, Leiser SC, Pangalos MN, Randall AD (2011) Altered intrinsic neuronal excitability and reduced $\mathrm{Na}+$ currents in a mouse model of Alzheimer's disease. Neurobiol Aging 32: 2109.e1-14. CrossRef Medline

Busche MA, Eichhoff G, Adelsberger H, Abramowski D, Wiederhold KH, Haass C, Staufenbiel M, Konnerth A, Garaschuk O (2008) Clusters of hyperactive neurons near amyloid plaques in a mouse model of Alzheimer's disease. Science 321:1686-1689. CrossRef Medline

Busche MA, Chen X, Henning HA, Reichwald J, Staufenbiel M, Sakmann B, Konnerth A (2012) Critical role of soluble amyloid- $\beta$ for early hippocampal hyperactivity in a mouse model of Alzheimer's disease. Proc Natl Acad Sci USA 109:8740-8745. CrossRef Medline

Cacucci F, Yi M, Wills TJ, Chapman P, O'Keefe J (2008) Place cell firing correlates with memory deficits and amyloid plaque burden in Tg2576 Alzheimer mouse model. Proc Natl Acad Sci USA 105:7863-7868. CrossRef Medline

Canto CB, Witter MP (2012a) Cellular properties of principal neurons in the rat entorhinal cortex. I. The lateral entorhinal cortex. Hippocampus 22:1256-1276. CrossRef Medline

Canto CB, Witter MP (2012b) Cellular properties of principal neurons in the rat entorhinal cortex. II. The medial entorhinal cortex. Hippocampus 22:1277-1299. CrossRef Medline

Cappaert NL, Van Strien NM, Witter MP (2015) Hippocampal formation. In: The rat nervous system (Paxinos G, ed), Ed 4, pp 511-573. San Diego: Academic Press.

D'Amelio M, Rossini PM (2012) Brain excitability and connectivity of neuronal assemblies in Alzheimer's disease: from animal models to human findings. Prog Neurobiol 99:42-60. CrossRef Medline

D'Andrea MR, Nagele RG, Wang HY, Lee DH (2002) Consistent immunohistochemical detection of intracellular $\beta$-amyloid42 in pyramidal neurons of Alzheimer's disease entorhinal cortex. Neurosci Lett 333:163-166. CrossRef Medline 
de Calignon A, Polydoro M, Suárez-Calvet M, William C, Adamowicz DH, Kopeikina KJ, Pitstick R, Sahara N, Ashe KH, Carlson GA, Spires-Jones TL, Hyman BT (2012) Propagation of tau pathology in a model of early Alzheimer's disease. Neuron 73:685-697. CrossRef Medline

Dong H, Martin MV, Chambers S, Csernansky JG (2007) Spatial relationship between synapse loss and beta-amyloid deposition in Tg2576 mice. J Comp Neurol 500:311-321. CrossRef Medline

Duffy AM, Morales-Corraliza J, Bermudez-Hernandez KM, Schaner MJ, Magagna-Poveda A, Mathews PM, Scharfman HE (2015) Entorhinal cortical defects in Tg2576 mice are present as early as 2-4 months of age. Neurobiol Aging 36:134-148. CrossRef Medline

Erchova I, Kreck G, Heinemann U, Herz AV (2004) Dynamics of rat entorhinal cortex layer II and III cells: characteristics of membrane potential resonance at rest predict oscillation properties near threshold. J Physiol 560:89-110. CrossRef Medline

Fuchs EC, Neitz A, Pinna R, Melzer S, Caputi A, Monyer H (2016) Local and distant input controlling excitation in layer II of the medial entorhinal cortex. Neuron 89:194-208. CrossRef Medline

Garcia-Marin V, Blazquez-Llorca L, Rodriguez JR, Boluda S, Muntane G, Ferrer I, Defelipe J (2009) Diminished perisomatic GABAergic terminals on cortical neurons adjacent to amyloid plaques. Front Neuroanat 3:28. CrossRef Medline

Gómez-Isla T, Price JL, McKeel DW Jr, Morris JC, Growdon JH, Hyman BT (1996) Profound loss of layer II entorhinal cortex neurons occurs in very mild Alzheimer's disease. J Neurosci 16:44914500. CrossRef Medline

Gouras GK, Tsai J, Naslund J, Vincent B, Edgar M, Checler F, Greenfield JP, Haroutunian V, Buxbaum JD, Xu H, Greengard P, Relkin NR (2000) Intraneuronal Abeta42 accumulation in human brain. Am J Pathol 156:15-20. CrossRef Medline

Grant SM, Ducatenzeiler A, Szyf M, Cuello AC (2000) Abeta immunoreactive material is present in several intracellular compartments in transfected, neuronally differentiated, P19 cells expressing the human amyloid beta-protein precursor. J Alzheimers Dis 2:207-222. CrossRef Medline

Grinvald A, Frostig RD, Lieke E, Hildesheim R (1988) Optical imaging of neuronal activity. Physiol Rev 68:1285-1366. CrossRef Medline

Gu N, Vervaeke K, Storm JF (2007) BK potassium channels facilitate high-frequency firing and cause early spike frequency adaptation in rat CA1 hippocampal pyramidal cells. J Physiol 580:859-882. CrossRef Medline

Haass C, Selkoe DJ (2007) Soluble protein oligomers in neurodegeneration: lessons from the Alzheimer's amyloid beta-peptide. Nat Rev Mol Cell Biol 8:101-112. CrossRef Medline

Hanzel CE, Pichet-Binette A, Pimentel LS, lulita MF, Allard S, Ducatenzeiler A, Do Carmo S, Cuello AC (2014) Neuronal driven pre-plaque inflammation in a transgenic rat model of Alzheimer's disease. Neurobiol Aging 35:2249-2262. CrossRef Medline

Hardy JA, Higgins GA (1992) Alzheimer's disease: the amyloid cascade hypothesis. Science 256:184-185. CrossRef Medline

Harris JA, Devidze N, Verret L, Ho K, Halabisky B, Thwin MT, Kim D, Hamto P, Lo I, Yu GQ, Palop JJ, Masliah E, Mucke L (2010) Transsynaptic progression of amyloid- $\beta$-induced neuronal dysfunction within the entorhinal-hippocampal network. Neuron 68: 428-441. CrossRef Medline

Hazra A, Gu F, Aulakh A, Berridge C, Eriksen JL, Ziburkus J (2013) Inhibitory neuron and hippocampal circuit dysfunction in an aged mouse model of Alzheimer's disease. PLoS One 8:e64318. CrossRef Medline

Heggland I, Storkaas IS, Soligard HT, Kobro-Flatmoen A, Witter MP (2015) Stereological estimation of neuron number and plaque load in the hippocampal region of a transgenic rat model of Alzheimer's disease. Eur J Neurosci 41:1245-1262. CrossRef Medline

Herrup K (2015) The case for rejecting the amyloid cascade hypothesis. Nat Neurosci 18:794-799. CrossRef Medline

Iulita MF, Allard S, Richter L, Munter LM, Ducatenzeiler A, Weise C, Do Carmo S, Klein WL, Multhaup G, Cuello AC (2014) Intracellular $\mathrm{A} \beta$ pathology and early cognitive impairments in a transgenic rat overexpressing human amyloid precursor protein: a multidimensional study. Acta Neuropathol Commun 2:61. CrossRef Medline Kellner V, Menkes-Caspi N, Beker S, Stern EA (2014) Amyloid- $\beta$ alters ongoing neuronal activity and excitability in the frontal cortex. Neurobiol Aging 35:1982-1991. CrossRef Medline

Kerrigan TL, Brown JT, Randall AD (2014) Characterization of altered intrinsic excitability in hippocampal CA1 pyramidal cells of the A $\beta$-overproducing PDAPP mouse. Neuropharmacology 79:515524. CrossRef Medline

Klink R, Alonso A (1993) Ionic mechanisms for the subthreshold oscillations and differential electroresponsiveness of medial entorhinal cortex layer II neurons. J Neurophysiol 70:144-157. CrossRef Medline

Klink R, Alonso A (1997) Morphological characteristics of layer II projection neurons in the rat medial entorhinal cortex. Hippocampus 7:571-583. CrossRef Medline

Kobro-Flatmoen A, Nagelhus A, Witter MP (2016) Reelinimmunoreactive neurons in entorhinal cortex layer II selectively express intracellular amyloid in early Alzheimer's disease. Neurobiol Dis 93:172-183. CrossRef Medline

Koganezawa N, Taguchi A, Tominaga T, Ohara S, Tsutsui K, Witter MP, lijima T (2008) Significance of the deep layers of entorhinal cortex for transfer of both perirhinal and amygdala inputs to the hippocampus. Neurosci Res 61:172-181. CrossRef Medline

Kordower JH, Chu Y, Stebbins GT, DeKosky ST, Cochran EJ, Bennett D, Mufson EJ (2001) Loss and atrophy of layer II entorhinal cortex neurons in elderly people with mild cognitive impairment. Ann Neurol 49:202-213. CrossRef Medline

Leon WC, Canneva F, Partridge V, Allard S, Ferretti MT, DeWilde A, Vercauteren F, Atifeh R, Ducatenzeiler A, Klein W, Szyf M, Alhonen L, Cuello AC (2010) A novel transgenic rat model with a full Alzheimer's-like amyloid pathology displays pre-plaque intracellular amyloid-beta-associated cognitive impairment. J Alzheimers Dis 20:113-126. CrossRef Medline

Li R, Singh M (2014) Sex differences in cognitive impairment and Alzheimer's disease. Front Neuroendocrinol 35:385-403. CrossRef Medline

Livak KJ, Schmittgen TD (2001) Analysis of relative gene expression data using real-time quantitative PCR and the 2(-delta delta $\mathrm{C}(\mathrm{T})$ ) method. Methods 25:402-408. CrossRef Medline

Marcantoni A, Raymond EF, Carbone E, Marie H (2013) Firing properties of entorhinal cortex neurons and early alterations in an Alzheimer's disease transgenic model. Pflugers Arch 466:14371450. CrossRef Medline

Marchetti C, Marie H (2011) Hippocampal synaptic plasticity in Alzheimer's disease: what have we learned so far from transgenic models? Rev Neurosci 22:373-402. CrossRef Medline

McLean CA, Cherny RA, Fraser FW, Fuller SJ, Smith MJ, Beyreuther K, Bush Al, Masters CL (1999) Soluble pool of Abeta amyloid as a determinant of severity of neurodegeneration in Alzheimer's disease. Ann Neurol 46:860-866. CrossRef Medline

Minkeviciene R, Rheims S, Dobszay MB, Zilberter M, Hartikainen J, Fulop L, Penke B, Zilberter Y, Harkany T, Pitkanen A, Tanila H (2009) Amyloid $\beta$-induced neuronal hyperexcitability triggers progressive epilepsy. J Neurosci 29:3453-3462. CrossRef Medline

Musiek ES, Holtzman DM (2015) Three dimensions of the amyloid hypothesis: time, space and 'wingmen'. Nat Neurosci 18:800-806. CrossRef Medline

Näslund J, Haroutunian V, Mohs R, Davis KL, Davies P, Greengard P, Buxbaum JD (2000) Correlation between elevated levels of amyloid beta-peptide in the brain and cognitive decline. JAMA 283: 1571-1577. CrossRef Medline

Nilsen LH, Melø TM, Witter MP, Sonnewald U (2014) Early differences in dorsal hippocampal metabolite levels in males but not females in a transgenic rat model of Alzheimer's disease. Neurochem Res 39:305-312. CrossRef Medline

Palop JJ, Mucke L (2010a) Amyloid-beta-induced neuronal dysfunction in Alzheimer's disease: from synapses toward neural networks. Nat Neurosci 13:812-818. CrossRef Medline 
Palop JJ, Mucke L (2010b) Synaptic depression and aberrant excitatory network activity in Alzheimer's disease: two faces of the same coin? Neuromolecular Med 12:48-55. CrossRef Medline

Palop JJ, Chin J, Roberson ED, Wang J, Thwin MT, Bien-Ly N, Yoo J, Ho KO, Yu GQ, Kreitzer A, Finkbeiner S, Noebels JL, Mucke L (2007) Aberrant excitatory neuronal activity and compensatory remodeling of inhibitory hippocampal circuits in mouse models of Alzheimer's disease. Neuron 55:697-711. CrossRef Medline

Paxinos G, Watson C (2007) The rat brain in stereotaxic coordinates, Ed 6. New York: Elsevier/Academic Press.

Price JL, Ko Al, Wade MJ, Tsou SK, McKeel DW, Morris JC (2001) Neuron number in the entorhinal cortex and CA1 in preclinical Alzheimer disease. Arch Neurol 58:1395-1402. CrossRef Medline

Qi Y, Klyubin I, Harney SC, Hu N, Cullen WK, Grant MK, Steffen J, Wilson EN, Do Carmo S, Remy S, Fuhrmann M, Ashe KH, Cuello AC, Rowan MJ (2014) Longitudinal testing of hippocampal plasticity reveals the onset and maintenance of endogenous human $A ß$-induced synaptic dysfunction in individual freely behaving preplaque transgenic rats: rapid reversal by anti-A $B$ agents. Acta Neuropathol Commun 2:175. CrossRef Medline

Scala F, Fusco S, Ripoli C, Piacentini R, Li Puma DD, Spinelli M, Laezza F, Grassi C, D'Ascenzo M (2015) Intraneuronal A $\beta$ accumulation induces hippocampal neuron hyperexcitability through A-type $\mathrm{K}(+)$ current inhibition mediated by activation of caspases and GSK-3. Neurobiol Aging 36:886-900. CrossRef Medline

Scharfman HE, Sollas AL, Smith KL, Jackson MB, Goodman JH (2002) Structural and functional asymmetry in the normal and epileptic rat dentate gyrus. J Comp Neurol 454:424-439. CrossRef Medline

Schmidt H, Gour A, Straehle J, Boergens KM, Brecht M, Helmstaedter M (2017) Axonal synapse sorting in medial entorhinal cortex. Nature 549:469-475. CrossRef Medline

Selkoe DJ (2008) Soluble oligomers of the amyloid beta-protein impair synaptic plasticity and behavior. Behav Brain Res 192:106113. CrossRef Medline

Seress L, Pokorny J (1981) Structure of the granular layer of the rat dentate gyrus. A light microscopic and Golgi study. J Anat 133: 181-195. Medline

Shah K, McCormack CE, Bradbury NA (2014) Do you know the sex of your cells? Am J Physiol Cell Physiol 306:C3-C18. CrossRef Medline

Shao LR, Halvorsrud R, Borg-Graham L, Storm JF (1999) The role of BK-type $\mathrm{Ca} 2+-$ dependent $\mathrm{K}+$ channels in spike broadening during repetitive firing in rat hippocampal pyramidal cells. J Physiol 521[Pt 1]:135-146. CrossRef Medline

Simić G, Kostović I, Winblad B, Bogdanović N (1997) Volume and number of neurons of the human hippocampal formation in normal aging and Alzheimer's disease. J Comp Neurol 379:482-494. CrossRef Medline
Storm JF (1987) Action potential repolarization and a fast afterhyperpolarization in rat hippocampal pyramidal cells. J Physiol 385:733-759. CrossRef Medline

Tamamaki N, Nojyo Y (1993) Projection of the entorhinal layer II neurons in the rat as revealed by intracellular pressure-injection of neurobiotin. Hippocampus 3:471-480. CrossRef Medline

Tahvildari B, Alonso A (2005) Morphological and electrophysiological properties of lateral entorhinal cortex layers II and III principal neurons. J Comp Neurol 491:123-140. CrossRef Medline

Thal DR, Rüb U, Orantes M, Braak H (2002) Phases of A betadeposition in the human brain and its relevance for the development of AD. Neurology 58:1791-1800. CrossRef Medline

Verret L, Mann EO, Hang GB, Barth AM, Cobos I, Ho K, Devidze N, Masliah E, Kreitzer AC, Mody I, Mucke L, Palop JJ (2012) Inhibitory interneuron deficit links altered network activity and cognitive dysfunction in Alzheimer model. Cell 149:708-721. CrossRef Medline

Wang J, Tanila H, Puoliväli J, Kadish I, van Groen T (2003) Gender differences in the amount and deposition of amyloidbeta in APPswe and PS1 double transgenic mice. Neurobiol Dis 14:318327. Medline

Waters J, Helmchen F (2006) Background synaptic activity is sparse in neocortex. J Neurosci 26:8267-8277. CrossRef Medline

West MJ, Coleman PD, Flood DG, Troncoso JC (1994) Differences in the pattern of hippocampal neuronal loss in normal ageing and Alzheimer's disease. Lancet 344:769-772. CrossRef Medline

Witter MP, Groenewegen HJ, Lopes da Silva FH, Lohman AH (1989) Functional organization of the extrinsic and intrinsic circuitry of the parahippocampal region. Prog Neurobiol 33:161-253. CrossRef Medline

Wright BJ, Jackson MB (2014) Long-term potentiation in hilar circuitry modulates gating by the dentate gyrus. J Neurosci 34:97439753. CrossRef Medline

Wykes R, Kalmbach A, Eliava M, Waters J (2012) Changes in the physiology of CA1 hippocampal pyramidal neurons in preplaque CRND8 mice. Neurobiol Aging 33:1609-1623. CrossRef Medline

Wyss JM (1981) An autoradiographic study of the efferent connections of the entorhinal cortex in the rat. J Comp Neurol 199:495512. CrossRef Medline

Xu W, Fitzgerald S, Nixon RA, Levy E, Wilson DA (2015) Early hyperactivity in lateral entorhinal cortex is associated with elevated levels of A $\beta$ PP metabolites in the Tg2576 mouse model of Alzheimer's disease. Exp Neurol 264:82-91. CrossRef Medline

Yu EP, Dengler CG, Frausto SF, Putt ME, Yue C, Takano H, Coulter DA (2013) Protracted postnatal development of sparse, specific dentate granule cell activation in the mouse hippocampus. J Neurosci 33:2947-2960. CrossRef Medline 